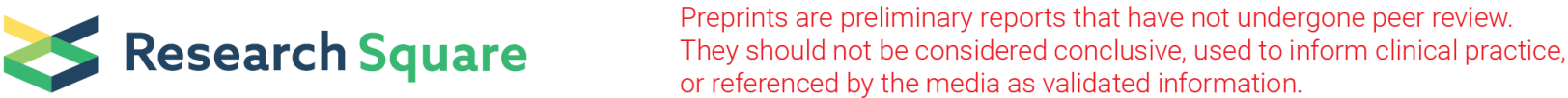

\section{The Temporal Clustering of Storm Surge, Wave Height, and High Sea Level Exceedances Around the UK Coastline}

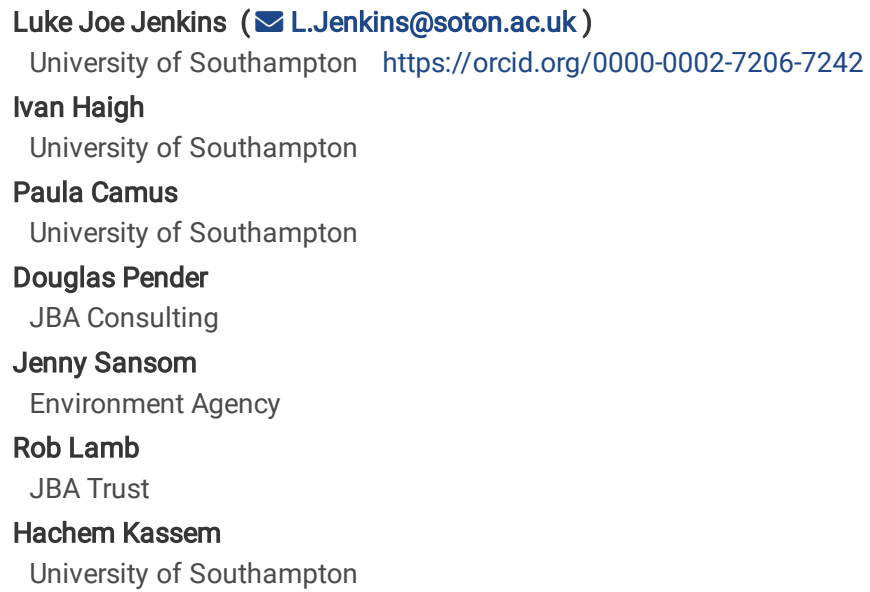




\section{Abstract}

The temporal clustering of storms presents consecutive storm surge and wave hazards that can lead to amplified flood and erosional damages; thus, clustering is important for coastal stakeholders to consider. We analyse the prevalence of storm clustering around the UK coastline by examining the temporal and spatial characteristics of storm surge, wave height, and high still sea level exceedances at the 1 in 1-and 5-year return levels. First, at the interseasonal timescale, we show that there are periods of high/low exceedance counts on national and regional scales. Elevated seasonal counts of lower-magnitude exceedances can occur without a respective signal of higher-magnitude exceedances. Secondly, at the intraseasonal timescale, we show that high proportions of exceedances are clustering within seasons. Storm surge, wave height and still sea level exceedances occurring $<50$ days after the prior account for $\sim 35-$ $44 \%$ ( 15-22\%) of those at the 1 in 1- (5-) year return level. Still sea levels have the highest degree of clustering, with $\sim 25 \%$ of 1 in 1 -year exceedances occurring $<2$ days after the previous. Spatially, for UK storm surges and still sea levels, the North Sea has the lowest proportion of clustering, whereas the North Atlantic and Bristol Channel have the highest. For English wave records, the North Sea and English Channel have the highest proportion of clustered lower- and higher-magnitude exceedances, respectively. These findings illuminate the prevalence of the clustering of coastal hazards around the UK - helping coastal stakeholders evaluate the threat of surges, waves, and sea levels clustering over short periods.

\section{Introduction}

Coastal areas represent a small percentage of the world's land surface $(\sim 2 \%)$ but contain a disproportionately high proportion of the world's population. Kulp and Strauss (2017) estimated that 1 billion people current occupy land $<10 \mathrm{~m}$ above current high tides levels with 230 million of those living on land $<1 \mathrm{~m}$ above high tide levels. Many of these people are exposed to coastal flooding and erosion.Over the last century, on average over 8 thousand people have been killed and 1.5 million people are affected annually by high sea levels (Bouwer and Jonkman, 2018).Average global flood losses in 2005 for the world's major coastal cities was estimated at $\sim \$ 6$ billion per year. This is predicted to rise to $\$ 60-63$ billion per year in 2050 even if adaptations maintain constant flood probability (Hallegatteet al. 2013). Without adaptation to sea-level rise, up to $4.6 \%$ of the global population is expected to be flooded annually in 2100 , with expected annual losses of such flooding being up to $9.3 \%$ of global gross domestic product (Hinkelet al. 2014). Currently, around $24 \%$ of sandy beaches around the world are eroding (Luijendijket al. 2018), and increased lengths of coastline will be exposed to increased erosion in the future (Vousdoukaset al. 2020). The United Kingdom (UK) coastal zone is home to over 5.3 million people in English and Welsh townsalone (Office for National Statistics, 2020), and holds great value to the economy, culture, and the environment. Annual average economic damages from coastal flooding in the UK are estimated to be $£ 540$ million(Sayers et al. 2017) and 28\% of the English \& Welsh coastline is already experiencing rapid erosion (Masselinket al. 2020). Therefore, improving the understanding of the causes and related impacts of coastal flooding and erosion is of great importance for effective adaptation and management strategies.

In this paper we focus on the temporal 'clustering' of storm surges,wave heights, and high still sea levelsaround the UK coast, which can strongly influence coastal flooding and erosion. The issues associated with storm clustering (i.e., events occurring one after another in close succession, also referred to as storm sequencing) were brought to particular attention in the UK during the extreme winter season of 2013/14 (Spencer et al. 2015; Wadeyet al. 2014; Haigh et al. 2016). Multiple, intense extratropical storms impacted the UK coastline during this winter period, with an average of 1 intense storm every two and a half daysin December-February (Priestley et al. 2017b). Storm clusteringcould lead to amplified flood and erosion damage as the attritional effects of the temporal clustering of high still sea levels, storm surges and waves are augmented by a lack of recovery or repair time. Therefore, not accounting for clustering could lead to a potential underestimation of coastal flood and erosion risk. Furthermore, rising mean sea levels driven by climate change and possible changes in storminess (Dangendorfet al. 2017; Nerem et al. 2018; Garner et al. 2018; Fox-Kemper et al. 2021) will likely lead to increased clustering of storm surges, waves, and high still sea levels, further exacerbating the impacts of flooding and erosion. Therefore, improved understanding of storm clustering around the coastlines of the UK is crucial in mitigating against storm damages into the future and assisting coastal management and planning.

Over the last decade, studies have started to examine storm clustering from a storm surge, wave and/or high still sea level perspective. For example, Godoi et al. (2017) and Stephens et al. (2020) assessed clustering in high still sea levels and waves around the coastline of New Zealand and linked this to patterns of mean sea level anomaly and large-scale ocean-atmosphere oscillations.In the UK, Wadeyet al. (2014) and Haigh et al. (2016) undertook assessments of the temporal clustering of high still sea levels and storm surges, and Santos et al. (2017) and Dhoop and Mason (2018) assessed clustering in waves. These studies showed that extreme wave events can cluster over short periods (Santoset al. 2017), whereas tidal forcing of sea levels restricts successive high still sea levels from occurring within 4-8 days of each other as one surge event will be at neap tide (Haigh et al. 2016). The majority (86\%) of high still sea levels are caused by high spring tides that coincide with a moderate skew surge (Haigh et al. 2016). Spatially, similar storm tracks have been shown to have broad, regional-scale footprints of high still sea levels and waves (Haigh et al. 2016; Santoset al. 2017; Dhoop and Mason, 2018). Typically, however,high still sea levels that occur in close succession (<4 days) affect different parts of the UK coastline (Haigh et al. 2016), whereas the number of days between extreme wave events were found to be similar among sites from the same region (Santos, Haigh and Wahl, 2017). The impact of the clustering of storm surges, waves and high still sea levels at the coast are varied and determined by a variety of site- and event-specific factors affecting beach vulnerability(Eichentopfet al. 2019). These complex site- and event-specific factors determine exactly how a storm cluster affects a beach, but studies have shown that the cumulative erosional effects of a storm sequence can be greater than a single more powerful storm (e.g., Karunarathna et al. 2013; Dissanayake et al. 2015). Research has also found that particularly stormy seasons can have long lasting impacts on beach morphology. Atlantic coast beaches in Europe affected by the extreme 2013/14 winter season had not recovered four years later (Dodetet al. 2018).

Our overall aim in this paper is to assess the nature of temporal clustering of storm surges, wave heights,and high still sea levels in measured and modelled time-series at sites around the UK coast. We build on the earlier work of Haigh et al.(2016), Santos et al.(2017), Dhoop and Mason (2018) but instead of analysing surges/still sea levels and waves separately, we analyse them together using a consistent approach. We also undertake an analysis at each gauge site individually, whereas these three previous studies focused on analysis of extreme events across sites, making it more difficult to quantify whether clustering is an issue at an individual site. We also extend the previous studies by comparing and contrasting measured and modelling hindcast time series.

Page $2 / 30$ 
We have two specific objectives, as follows:

1. To assess the characteristics of clustering on interseasonal timescales, determining in which seasons clustering was most apparent; and

2. To examine the characteristics of clustering on intraseasonaltimescales, analysing the number of days between consecutive exceedances.

We undertake our analysis considering and contrasting measured and modelled still sea level records at 46 tide gauge sites, and wave datasets at 43 sites. We identify all storm surge, wave heights and high still sea levels that exceed two thresholds, namely, the 1 in 1-year threshold and the 1 in 5 -year threshold. We choose the 1 in 1-year threshold to represent levels that are common enough to be seen throughout the time-series and to ensure a higher number of exceedances are identified, thus allowing clustering to be more readily identified. The 1 in 5 -year thresholds represent more extreme levels that are less frequent. The 1 in 5-year level also ensures high still sea levels arise as a result of a storm surge, and not solely a large astronomical tide (lunar perigean cycle causes tides to reach a maximum every 4.4 years; Haighet al. 2011). To assess clustering on interseasonal timescales, we examine the number of exceedances of storm surges, wave heights and high still sea levels each season. Note, a season is defined as being from $1^{\text {st }} \mathrm{July}$ to $30^{\text {th }}$ of June the next year, to encompass the northern hemisphere winter storm season. To assess clustering on intraseasonal timescales, we examine the number of daysbetween consecutive exceedances. We assess how well the modelled hindcasts capture the characteristics of storm clustering, compared to the measured records.

The structure of the paper is as follows. The data used is described in Section 2. The methodology is discussed in Section 3. Results are presented in Section 4, and key findings discussed in Section 5. Lastly, conclusions are given in Section 6.

\section{Data}

Six main data sources are used in this study and are described below.

The first dataset we use is high-frequency measured still sea level records from the UK National Tide Gauge Network, which comprises 43 operational 'A-class' tide gauges around the coast of the UK. There are also a small number of tide gauges that are no longer operational, for which historical records are available. Sea level records were downloaded from the 46 gauges for which there was processed data (the 43 'A-class' gauges plus 3 historical gauges). This was obtained from the British Oceanographic Data Centre (BODC), who are responsible for the monitoring, data retrieval, and quality control of the tide gauge network. The tide gauge network forms part of the UK Coastal Flood Forecasting (UKCFF) service, a partnership formed by the Environment Agency (EA), Scottish Environment Protection Agency (SEPA) Department for Agriculture and Rivers Agency Northern Ireland (RANI) and Natural Resources Wales (NRW). Values flagged as suspect by the BODC quality control were excluded from the datasets. The still sea levels were converted relative to ordnance datum Newlyn (ODN). Data is provided to the end of July 2021, with values prior to 1993 in hourly temporal intervals, and values after 1993 in 15 -minute intervals. The longest and shortest data records are Newlyn (106 years) and Moray Firth (10 years), respectively. The average data length is 45 years and the average data coverage after flags are removed is $81.3 \%$. The location and durations of the tide gauge sites are listed in Tables 1 and 2 and locations are shown in Figure $1 \mathrm{a}$.

The second dataset consisted of modelled hindcast still sea levels from the Coastal Dataset for the Evaluation of Climate Impact (CODEC). CODEC consists of a historical climate period (1979-2018) and a future climate period (2040-2100), under different climate change scenarios. To create the historical dataset (CODEC-ERA5), which is used in this research, the third generation Global Tide and Surge Model (GTSM) was forced with 10-metre wind speeds and atmospheric pressures from the Fifth Generation of ECMWF Atmospheric Reanalyses of the Global Climate (ERA5). GTSMv3.0 is a depth-averaged hydrodynamic model that is built from the unstructured Delft3D Flexible Mesh software. CODEC-ERA5 has aresolution of $1.25 \mathrm{~km}$ along the European coast. The nearest grid node to each EA tide gauge site was selected and the still sea levels extracted at a 10-minute temporal resolution. This gave still sea level data from the CODEC-ERA5 that is comparable to the observed levels from EA tide gauges. More detailed information about CODEC can be found in Muiset al. (2020). The location of the CODEC grid points closest to the tide gauge sites are shown in Figure 1a.

The third dataset comprised of return periods for still sea levels. The annual exceedance probabilities for all tide gauge sites in the UK National Tide Gauge Network were gained from the EA's 'Coastal flood boundary conditions for the UK: update 2018' (CFB) report. The return periods range from 1-year to 10,000years. The CFB report (2011) created a new statistical method, the Skew Surge Joint Probability Method (Bastoneet al. 2013), that was used to estimate return periods/levels for the majority of the UK National Tide Gauge Network. The 2018 update to the first CFB report utilised 10 years of additional data to extend the tide gauge records and made significant improvements to the statistical methods. Exceedance probabilities were calculated for missing tide gauge sites, such as those in Northern Ireland, and the temporal interpolation of return periods/levels from the hindcast reduced to $2 \mathrm{~km}$ or less.

The fourth dataset consisted of wave measurements obtained from the Channel Coast Observatory (CCO). This database contains 52 wave sites around the English coastline: 42 directional waverider buoys (DWR); 6 wave radar's (WaveREX); 3 step gauges; and one pressure array. CCO wave data was chosen over other UK buoy networks, such as WaveNet from the Centre for Environment, Fisheries and Aquaculture (CEFAS), as the CCO buoys tend to be closer to the shore and as suchare more suitable for the characterisation of events affecting the coastline; however, it does limit the analysis to England. Data is delivered in 30-minute intervals and each site is also provided with return periods/levels.Operational wave sites have data up to the end of September 2021.The West Anglesey wave buoy was omitted as it does not have quality-controlled data available. Values flagged by CCO quality control were excluded from the research, as well as six further sites whose exceedance probabilities have not been calculated. These sites were: Sandown Pier; Lymington; Swanage Pier; Teignmouth Pier; Port Isaac; and Severn Bridge. The longest and shortest data records are Milford (25 years) and New Brighton (1.7 years), respectively. The average data length is 11 years and the average data coverage after flags are removed is $92.8 \%$. The locations and durations of the wave sites are listed in Table 3 and locations are shown in Figure $1 \mathrm{~b}$.

The fifth dataset we use was modelled hindcast significant wave heights (Hs) from ERA5. ERA5 replaced ERA-Interim and is based on thelntegrated Forecasting System (IFS) Cy41r2. For waves, ERA5 has a much higher resolution of 40km compared to its predecessor (100km).Data isprovided at an hourly temporal resolution from 1979 up to current day with a latency of around 5 days. In this research we use wave data from 1979 to the $1^{\text {st }}$ January 2020 .The

Page $3 / 30$ 
availability of data back through time gives a farlonger time period of wave data than any of the UK buoy networks. This data is also gap-free, coincident with the CODEC dataset, and allows for analysis anywhere around the UK coastline.We extracted datafromthe nearest grid point to each CCO wave site to give comparable time-series.More information about the wave hindcast can be found inHersbachet al. (2020). The location of the ERA5 grid points closest to the cCOwave sites are shown in Figure 1b.

The sixthdataset comprisedof return periods for measured observations of high wave heights. These were obtained from CCO. These exceedance probabilities are calculated by fitting a generalised pareto distribution onto observations designated through the peak-over-threshold method that is combined with a storm separation window (Dhoop and Thompson, 2018).

\section{Methodology \\ 3.1 Data Preparation}

In this paper we first focus on analysing time-series of: (1) storm surges; (2) significant wave height; and (3) still sea level, offset for mean sea level (MSL) rise. We focus mainly on the first two time-series, as storm surges and waves are stochastic and primarily driven by meteorology -they therefore are most strongly influenced by storm clustering. In contrast, still sea levels include the deterministic tidal component driven by astronomical forces. However, as it is the stillsea level (e.g., tides plus storm surges) realised at the coast that drives coastal flooding and erosion, we also consider clustering in stillsea level.

The data preparationconsists of two main steps. The first step involves generating time-series of different components of still sea level, as follows: (1) the non-tidal (i.e., storm surge) component of still sea level, (2) significant wave height, and (3) still sea levels offset by MSL rise. Significant wave height timeseries were provided directly by the data source and we use the raw measurements. The other two time-series were calculated, as described below. The second step was to calculate the exceedance probabilities (i.e., return period levels) of each new time-series.

In the first step, we derive the two records not provided by the data sources, namely;(1) the non-tidal residual, which mostly contains the storm surge component, and(2) still sea levels offset by MSL rise. To extract the first time-series, the non-tidal residual, we computed the astronomical tidal component and removed this and MSL from the measured still sea level record. The tidal component was calculated using the MATLAB Unified Tidal Analysis and Prediction Functions(U-Tide) (Codiga, 2021). Tidal constituents were selected by U-Tide's automated decision tree method and used for tidal analyses of each calendar year. The decision tree is based on the equilibrium tide and the Rayleigh criterion. For any year containing $<50 \%$ data, the constituents from the nearest year containing $>50 \%$ of data were used. The tidal component for each gauge was then removed from the observed still sea level, along with MSL, to leave the non-tidal residual. The modelled hindcast data was already provided with the tidal component from the data source, so this was removed from the modelled still sea levels to obtain the modelled non-tidal residual. Hereafter, we use the term surge, or storm surge,to refer to the non-tidal residual.

Because MSL's have risen around the UK coast (Hogarth et al. 2021), we would expect there to be more highstill sea level exceedances in recent decades; and this is what we observe in the data. The rise of MSL brings the 'base' still sea level higher, therefore meaning that less input is required from the storm surge component of still sea levels to raise the overall levels above critical thresholds. As smaller storm surges are more common than large storm surges, with a rise in MSL you would expect to see a consequent rise in threshold exceedances. Thus, for the second time-series, we remove the influence ofMSL rise, so that storm clustering can be better compared without the MSL influence that biases extreme events to more recent years. To offset observed still sea levels, MSL trends at each tide gauge site were estimated using a linear regression method utilised by multiple previous sea levels studies (Woodworth et al. 2009; Haigh, Nicholls and Wells, 2009; Haigh et al. 2015; Haigh et al. 2016). This method interpolates linear annual mean sea level trends at tide gauges to hourly timeseries and then removes them. This leaves the interannual mean sea level variability. Hereafter, still sea level refers to still sea level offset by MSL rise.

In a second step, we identify all the exceedances at each site, in the three time-series we analyse, at or above the 1 in 1 - and 1 in 5 -year return period thresholds. As discussed in Section 2, return levels are available for the measured still sea level and wave height records, but not for the measured non-tidal residual or for the modelled hindcast time-series. Hence, we computed our own return periods for these datasets. We use a similar method to that of Dhoop and Mason, (2019). Using the peaks-over thresholds method (POT), we extracted all data above the $99^{\text {th }}$ percentile. To decluster the data, and ensure unique peaks were identified, we used the 'storm window' approach of Haigh et al. (2016). We removed all values that were within plus or minus 16 hours of each peak value. This period was chosen, as most storm surges last for approximately 32 hours (see Supplementary Figure S1 and S2). We fit a Generalised Pareto Distribution to the identified peaks at each site to gain estimates for return levels. Exampletime-series of measuredstorm surge, significant wave height and high still sea levelsare shown in Figure 2 for Newhaven (tide gauge) and Seaford (wave buoy), along with the levels identified to be above the chosen thresholds.

\subsection{Interseasonal Timescale Analysis}

Next,we address the first objective, which is to assess the characteristics of clustering around the UK coast on interseasonal timescales. To do this we analyse the spatial and temporal characteristics of seasonal counts of exceedances. The winter storm season was selected as extending from the $1^{\text {st }}$ July to the $30^{\text {th }}$ June the following year. Seasonal exceedances above the 1 in 1- and 5-year return level threshold of each measured and modelled parameter were counted at each site.An example is shown for Newhaven (tide gauge) and Seaford (wave buoy) in Figure 3.The timings of all measured exceedances werethenaggregated to show when in the year they occurred (see Supplementary Figure S3). The seasonal counts for each site were collatedand presented together to show changes around the UK. Tide gauges around the UK were grouped into the five broad regions shown in Figure 1a that represent different parts of the UK coastline. The wave sites around England were also grouped into five regions shown in Figure 1bthat represent broad portions of the English coast. The higher density of wave sites meant that $13 \mathrm{CCO}$ sites shared the same nearest ERA5 grid nodes.Modelled data was compared to the measured data to see how well the hindcasts represented seasons with a high number of exceedances. For the surge and still sea level time-series, we focus on the time period of $1979-2021$

Page 4/30 
as it includes the time period from the CODEC dataset and measured data availability before this period is relatively sparse.For the waves time-series, we also focus on the same time-period as it includes the time period of the modelled ERA5 dataset. However, theshort wave records of measured data means that most sites only have data availability from the early 2010's and interseasonal change for all regions can only be discussed for the last decade.

\subsection{Intraseasonal Timescale Analysis}

Finally, we address the second objective, which is to examine the characteristics of clustering on the intraseasonal timescale.To achieve this, we analyse the number of days between consecutive exceedances. This was carried out for all parameters and sitesat the 1 in 1-and 5-year threshold before being aggregated together for UK-wide and regional analysis. Modelled data was not included in the second objective due to the differences seen between measured and modelled data while undertakingthe first objective, as is discussed later in the paper.

\section{Results}

\subsection{Interseasonal (Seasonal exceedances)}

The first objective is to assess the characteristics of clustering around the UK coast on interseasonal timescales. To do this we assess the number of exceedances per season from 1979/80 to 2021/22 above the 1 in 1-and 1 in 5-year thresholds in each of the three measured and modelled time-series andexamine how this varies in time and spatially among sites. The number of exceedances above the 1 in 1 -and 1 in-5-year thresholds are plotted in Figures 4 , 5 and 6 for surge, wave and still sea level, respectively. In each of these three figures the: 1 in 1 -year exceedances are plotted in panels (a) and (b) and 1 in 5 year exceedances in panels (c) and (d); and measured data is plotted in figure panels (a) and (c) and the modelled data in panels (b) and (d). In these three figures, time (i.e., seasons $1979 / 90$ to $2021 / 22$ ) is represented on the $x$-axis and each site gauge is represented as a block on the $y$-axis, with the number of exceedances represented by a colour shading. On the y-axis the sites are plotted clockwise around the coast from Lerwick (at the top) for surges and still sea levels, and from Newbiggin for wave heights. The horizontal lines (blue: surges, red: wave heights and still sea levels) indicate the five regions shown in the inserted maps on the left side and in Figure 1. The total number of exceedances, and the number of seasons containing an exceedance for each site, is listed in Tables 1 and 2 for tide gauges and Table 2 for wave sites. Below we present the results, first for surges, then waves, and then still sea levels.

Storm Surge:First, we consider the measured storm surge component, shown in Figures4a and 4c. Without clustering, one might expect the 1 in 1-year exceedance to be reached each year at every site. However, it is evident in Figure 4a that some seasons have multiple 1 in 1-year exceedances across multiple sites, and some seasons have no exceedances at certain sites and in certain regions. The $2013 / 14$ season is the clear standout with the majority of UK gauges seeing elevated counts of threshold exceedances. Spatial coherence among sites in each of the five regions is apparent; i.e., if one site as a high number of exceedances, this is likely also apparent at the other sites within that region. Furthermore, in most seasons, exceedance counts are high across two or more of the five regions during the same season; at the 1 in 1-year level there is no year when exceedance counts are higher for just one of the fiveregions alone, implying that seasonal clustering impacts on large spatial scales across the UK. The number of surge exceedances at or above the 1 in 1 -year level are listed in Table 1. At all sites, the number of seasons when there was an exceedance is far less than the total number of seasons of data available, showing again that seasonal clustering is strongly prevalent in surge time-series. There were 161 storm surges exceedances in the $2013 / 14$ season at or above the 1 in 1 -year return level with 40 of the 42 operational tide gaugesexperiencing an exceedance this season. 33 (29) gauges experienced 2 (3) or more exceedances in 2013/14. The seasons at the 1 in 1-year return level threshold that havesimilar high counts of exceedances across a large spatial coverage are the $1992 / 93$ and 2006/07 seasons. The 2006/07 season saw 114 storm surge exceedances across 41 out of 44 operational gauges for the 1 in 1-year level. In 1992/93, there was a similar number of storm surge exceedances (115)at the 1 in 1-year level, but these exceedances were seen across 32 out of 40 operational UK gauges. The 1992/93 season was the beginning of a 9-season period (1992/93-2001/02)which contained 7 out of the top 10 seasons on record in terms of total number of UK-wide storm surge exceedances at or above the 1 in 1-year return level threshold.Other periods of elevated exceedance counts occur with smaller spatial footprints. The $2011 / 12$ season saw the second largest number of 1 in 1 -year surge exceedances in North Sea gauges. This was despite 5 of the 12 operational gauges seeing no exceedances. The other UK regions during this season,except the Irish Sea,saw relatively low counts of exceedances relative to the rest of thetime period (1979-2021) and the number of operational gauges.

At the 1 in 5-year return level threshold (Figure 4c), the rarity of exceedances of this magnitude is apparent, as expected given the higher threshold, with long periods of few exceedances for large parts of the UK coastline and a much smaller overall count of exceedances (Table 2). Like with the results from the 1 in 1 year threshold, some spatial coherence among sites in each of the fiveregions is apparent. However, with the exception of the 2013/14 season, exceedance counts are typically only higher across one or two of the five regions. This implies thatmeteorological forcing generallyresults in the seasonal clustering of smaller magnitude exceedances on a national scale, whereas the seasonal clustering of higher magnitude exceedances occur on a more local scale and are likely more reliant on storm paths.At the 1 in 5-year return level threshold, the 2013/14 season remains the most significant season on record with 52 storm surge exceedances. 33 of the 42 operational tide gauges saw at least 1 surge exceedance. The 1992/93 season sees the second highest seasonal total of 1 in 5 -year surge exceedances (32), but the spatial coverage is reduced. All but 3 of the surge exceedances occurred across 16 North Sea and North Atlantic tide gauges. Interestingly, the 2006/07 season that had a high number of 1 in 1-year return level surge exceedances does not see a matching signal at the 1 in 5 year return level. Each region has numerousmulti-season periods where zero, or very few, exceedances were seen. For example, between 2003/04-2018/19 in the English Channel, 1 in 5-year surge exceedances were only recorded in the 2013/14 season. There are also periods where it is evident that few exceedances occurred across the entire UK tide gauge network. The seasons ofthe early-mid 1980s saw many seasons containing few exceedances, but there were 18 or more tide gauges that were not yet operational in this period. In contrast, some recent seasons where nearly all tide gaugeswere operational recorded few surge exceedances at the national scale.The 2003/04 season recorded only 2 surge exceedances at only 1 gauge, the seasons of $2016 / 17$ and $2019 / 20$ only saw 1 exceedance each, and the 2009/10 seasonrecorded no surge exceedances across all operational UK gauges. 
The seasonal counts of the corresponding modelled storm surge extremes from the CODEC hindcast, at or above the 1 in 1-year and 1 in 5-year return level are shown in Figures $4 \mathrm{~b}$ and $4 \mathrm{~d}$, respectively. Interestingly, although the CODEC hindcast has been extensively validated against measured still sea level data (with small root mean square errors and mean absolute errors in the high-frequency time-series; see Muiset al. 2020), the counts in exceedances above higher thresholds do not appear to closely agree. This would suggest that while the hindcast accurately captures the mean characteristics of measured still sea level well, the more extreme levels are not as accurately predicted at the gauge locations. For the coincident time period (1979/80-2018/19), it is apparent that CODEC underestimates the total number of exceedances across all gauges at the 1 in 1-year return level (1771 to 1502 exceedances), and the 1 in 5 -year return level (382 to 179 exceedances), relative to the measured data.Differences in measured versus modelled total countsare alsolikely to be greater than stated, asthere is a significant proportion of measured data missing due to non-operational tide gauges,whilst the modelled hindcast provides continuous gapfree data throughout the time period.Although there issome coherence between the measuredseasonal storm surge exceedances and CODEC in relation to some ofthe periods of low, or no countsat the 1 in 1-year return level, the hindcast tends to overestimate the spatial footprint. The most evident difference between the modelled hindcast and the measured surge exceedances is the lessened signal of the 2013/14 season. It remains as one of the most significant seasons but does not dominate the record like in the measured surge record. Instead, the most significant season in the modelled hindcast records is $1989 / 90$. At the 1 in 1 (5)-year return level, 158 (37) surge exceedances were recorded across 40 (27) sites, whereas in 2013/14 there were 147 (31) exceedances across 44 (29) sites.

Wave:Next, we consider wave heights. The seasonal counts of measured high significant wave heights at each of the 45 waves site, at or above the 1 in 1 -year and 1 in 5 -year return level are shown in Figures $5 \mathrm{a}$ and $5 \mathrm{c}$, respectively.Due to the relatively short duration of measured wave data, it is more difficult to characterise interseasonal change. As with surge, the 2013/13 season stands out, with spatial coherence among sites being apparent in each of the five regions. The general pattern of wave exceedances is comparable to surge exceedances from the corresponding English tide gauges, but there are a greater number of neighbouring wave sites recording exceedances with the higher spatial density of wave sites.At the 1 in 1-year return level (Figure $5 a$ ), numbers of exceedances are fairly consistent across all regions throughout the short record, with only the 2012/13 season having a high number of sites not experiencing an exceedancewith most sites being operational. At the 1 in 5-year return level (Figure $5 \mathrm{c}$ ), the North Sea sites appear to more consistently experience seasons with exceedances, but this is difficult to characterise relative to the particularly short data lengths. For example, Chapel Point has 4 seasons with a wave height exceedance above the 1 in 1-year level out of only 9 seasons in its record (Table 3). Sites in the English Channel have been operational for longer and show that periods of elevated counts of 1 in 5 -year wave height exceedances can be preceded and/or followed by periods of no exceedances. There were only 81 in 5-year exceedances recorded between 2003/04-2012/13 across all operational sites in the English Channel and just one exceedance occurred between 2018/19-2020/21. In contrast, the extreme season of 2013/14 produced significantly higher exceedance counts in the English Channel. At both 1 in 1 - and 1 in 5-year return levels, the 2013/14 season has the highest number of exceedances across all sites and most instances of a site experiencing $>1$ exceedances in a season. This is primarily seen in English Channel wave sites. Across all sites and seasons of measured wave height data, 25\% of all 1 in 5 -year exceedances happened at English Channel sites in the 2013/14 season.

The seasonal exceedance counts of the modelled high significant wave heights from the closest ERA5 hindcast grid node to the corresponding wave site, at or above the 1 in 1-year and 1 in 5-year return level are shown in Figures $5 \mathrm{~b}$ and $5 \mathrm{~d}$, respectively. There are fewer ERA5 grid nodes than CCO wave sites due to the coarse resolution of the ERA5 wave hindcast.It is important to note that spatial coherencebetween sites in the modelled datawill be strengthened by the fact that 13 sites share the same ERA5 grid nodes.Due to short wave records, the modelled data can only be contrasted to the measured data for the last $\sim 10-15$ years. The 2013/14 season is seen to have a high number of counts and a large spatial footprint at both return levels. However, like with the modelled surge component, the 1989/90 season has a higher total of exceedance counts than 2013/14 (but it cannot be validatedwhether this is unusual from the measured data like it was with surge levels, as measured wave data is not available this far back in time at most sites).After the 2013/14 season, the

modelunderestimates the number of exceedances by 173 at the in 1-year level and 46 at the 1 in 5 -year level when compared to the measured data.Expectedly, there are some clear similarities in the general patterns seen between the ERA5 hindcast wave heights and the ERA5-forced CODEC surge exceedances as both are primarily driven by the meteorology of the ERA5 reanalysis. At the 1 in 1-year return level, the ERA5 seasonal exceedances closely resemble the CODEC seasonal exceedances at the English tide gauges.One of the only noteworthy differences is the strong wave signal in 1979/80 which is not seen at most English tide gauges in the modelled surges. Interestingly, when discounting the shared wave grid nodes and focusing on the 30 distinctEnglish wave grid nodesanalysed in the ERA5 hindcast, compared to 46 UK grid nodes analysed in the CODEC hindcast, the modelled wave data has 58 more exceedances than the surge hindcast at the higher 1 in 5 -year return level threshold. The modelled seasonal exceedances of wave heights also a higher level of spatial coherence, with 4 more seasons having 6 or more neighbouring sites all experiencing at least one exceedance, despite the lower overall number of sites. This further highlights the smaller spatial scales associated with the seasonal clustering of higher magnitude exceedances.

Still Sea Level:Finally, we consider high stillsea levels (e.g., tide plus surge, offset by MSL rise). The number of still sea level exceedances at or above the 1 in 1 -year and 1 in 5-year per season, is shown in Figure $6 \mathrm{a}$ and $6 \mathrm{c}$ for the measured data at each of the 46tide gauge sites.As with storm surges and waves, the 2013/14 season is the most significant season on record for the total number of UK-wide measured high still sea level exceedances at both the 1 in 1 - and 5 year return level threshold.There were 175 (68) high still sea level exceedances across 39 (34) of the 42 operational tide gauges at the 1 in 1- (5-) year return level. It is rare for a site to experience more than one 1 in 5-year still sea level exceedance in a season yet in 2013/14 this was the case for 21 gauges. The 2006/07 season had the second highest count of 1 in 1-year still sea level exceedances, experiencing 149 across 40 of 44 operational gauges. However, as with storm surges, this season does not see a matching signal of 1 in 5-year return level exceedances. Only 151 in 5 -year high still sea level exceedances were recorded across 12 gauges.Numerous 1 in 1-year return level exceedances that are clustered in the 1993/94 to 2001/02 period (Figure 6a) are also not represented to asimilar extent at the 1 in 5 -year return level. There are clear differences in the measured still sea levels compared to the measured seasonal storm surge exceedances (Figure 4a and 4c). Seasons that contain storm surge exceedances on local and regional scales do not necessarily see a corresponding signal of still sea level exceedances.At the lower 1 in 1-year return level,there are254 more measured still sea level exceedances than storm surge exceedances (Table 1). All regions except the North Sea recorded more still sea level exceedances than storm surge exceedances in the record. It is evident from Figures $6 \mathrm{a}$ and $4 \mathrm{a}$ that the higher number of still sea level exceedances are clustered spatially and temporally to a larger extent than the storm 
surge exceedances, as there is a greater number of seasons with nostill sea level exceedances at regional and national scales. The 9-season period (1992/932001/02) which contains 7 out of the top 10 seasons on record for 1 in 1-year return level surge exceedances, however, does also contain 7 of the top 10 seasons for high still sea level exceedances (6 matching seasons). Conversely, at the higher 1 in 5 -year return level threshold (Figure $6 \mathrm{c}$ ), there were $44 \mathrm{more}$ storm surge exceedances than high still sea level exceedances in the record (Table 2). This is despite both the North Atlantic and Bristol Channel regions recording more highstill sea level exceedances than storm surge exceedances. The North Sea saw the highest number of storm surge exceedances (121) and the greatest difference between the number of still sea level exceedances (44 more surge exceedances, 26 more than the next largest regional difference in theEnglish Channel) at the 1 in 5-year return level.

The number of modelled 1 in 1-and 5-year high stillsea level exceedances(again offset for MSL rise)from the CODEC hindcast is shown in Figure 6b and 6d for the grid nodes closestto each tide gauge.For the total count of exceedances across all gauges, the CODEC hindcast appears to better represents still sea level exceedances than surge exceedances at both 1 in 1- and 5-year thresholds for the coincident timeperiod. At the 1 in 1-year return level (Figure 6b), CODEC slightly underrepresents the measured data by a difference of 94 still sea level exceedances, whilst at the 1 in 5 -year return level (Figure 6d) CODEC slightly overestimates with 118 more modelled stillsea level exceedances. The modelled still sea level data is consistent with the some of the patterns seen across the modelled data for surges and waves. When exceedances occur in the modelled data, they tend to affect multiple neighbouring sites. The modelled still sea level data has over double the number of seasons where 10 or more neighbouring tide gauges experience at least one 1 in 1-year exceedance. The $2013 / 14$ season has a particularly reduced signal in the modelled still sea levels, despite having the third highest total count for a season; there were 87 (38) fewer exceedances compared to 1989/90. Like with surge levels, there is some coherence between measured and modelled still sea levels in relation to period of low, or no counts.

\subsection{Intraseasonal: Days-betweenexceedances}

The second objective is to examine the characteristics of clustering on intraseasonal timescales. To achieve this, we analyse the number of days between consecutive exceedances at or above the 1 in 1-and 5-year return levelsfor each of the threeparameters, at each gauge site.We do this only for the measured datasets and the entirety of the measured data records available. As highlighted in Section 4.1, the modelled hindcast datasets see key differenceswhen compared to the measured datasets in theseasonal count patterns of storm surge, wave height, and high still sea level exceedances.

The number of days between consecutive measured exceedances that occur within 365 days of the previous exceedance, at or above the 1 in 1 - and 5-year thresholds, are shown in $7 \mathrm{a}$ and $7 \mathrm{~b}$ for surge levels, $7 \mathrm{c}$ and $7 \mathrm{~d}$ for wave heights, and $7 \mathrm{e}$ and $7 \mathrm{f}$ for still sea levels, for all gauge sites available. Consecutive events occurring within 365 days of each other are evident at both return level thresholds. However, it is clear that therearemany more examples at the lower 1 in 1-year return level. Certain periods can be seen where many exceedancesappear to cluster over a similar time period, with numerousexceedances occurring within 365 days of the last.In each of the three parameters, there are a number ofexceedances that occurred within very small time periods (i.e., less than three days apart) for the 1 in 1-year threshold. Interestingly, there are many exceedances of still sea level at or less than 1 day, and between 6 and $\sim 10$ days (Figure 7e); a feature not seen in the surge (Figure 7a) and wave (Figure 7c) results. This is likely a result of the spring neap tidal cycle and confirms the findings of Haigh et al. (2016); when storms are separated by 4-8 days, one will always occur during neap tide, and the combined still sea level, even with a large storm surge, is unlikely to be high enough to lead to a high still sea level. As expected, given the higher threshold, there are much fewer occurrences of exceedances occurring within shorter periods at the 1 in 5-year level, particularly in the surge and wave records.

The total number of exceedances and the minimum, maximum, median, and average number of days between consecutive exceedances for each site is listed in Tables 1 and 2 for tide gauges and Table 3 for wave sites. At the 1 in 1-year return level, the clustering of exceedances is prevalent.For example, there are 1793still sea level exceedancesthat occur across all 45-gauge sites within 365 days of the last exceedance. However, at the 1 in 5 -year return level, the clustering of exceedances becomes far less apparent. Only 7\% of the 1793 still sea level exceedances at or above the 1 in 1-year are at or above the 1 in 5 year level.A similar proportion of 1 in 5 -year exceedances is seen across the other parameters analysed when compared to their respective 1 in 1 -year return level exceedance totals ( $7 \%$ for surges, $8 \%$ for waves).Nevertheless, the proportions of 1 in 5 -yearexceedances occurring in quick succession is still of significance given the rarity of exceedances of this magnitude.Importantly, all parameters see the highest number of the exceedances occurring on short temporal scalesin the periods of highest data availability. Therefore, it is likely that due to the drop off in data availability before the 1990's for tide gauge data, and the late 2000s for wave data, that a significant number of exceedances have been missed. The gap between many consecutive exceedancesmay also consequently be overestimated. Despite this, it is clear that significant numbers of exceedances are clustering over short periods.

Next, we consider the percentage of consecutive exceedances around the UK occurring at six different chosen timescales, namely: $<1-3$ days, 3-14 days, $14-50$ days, 50-100 days, 100-365 days, and $\geq 365$ days. Results are shown in Figure 8 for the three parameters, for both the 1 in 1 - and 1 in 5 -year thresholds. For all parameters, the majority (>65\%) of 1 in 1-year exceedances occur within 365 days of the previous exceedance. Importantly, significant proportions occur on far shorter timescales. $24 \%(\sim 44 \%)$ of still sea level exceedances occur within 3 (50) days of the previous exceedance. 10\% of storm surgeexceedances occur within 3 days and 26\% ( 39\%) occur within 14 (50) days of the previous exceedance. 20\% ( 35\%) of wave height exceedances occur within 14 (50) days. Of thestill sea levelexceedances occurring within 2 weeks of the last, $75 \%$ occur in less than 2 days(Supplementary Figure S4). At the 1 in 5-year return level, exceedances occurring within 365 days of the previous exceedance account for $\sim 26 \%$ of surge exceedances and $\sim 34 \%$ of still sea levelexceedances. Although there are 33 examples of quick succession still sea level exceedances occurring within 14 days of the last exceedance, all but one occurred within 4 days of the previous exceedance.

The percentage of consecutive exceedances at the six specified timescales are shown in Figure 9a-e for surge and still sea level, but this time averaged across the sites within the specific fiveUKregions (shown in Figure 1a) and again for all sites (Figure 9f). Spatially, clustered periods of 1 in 1-year exceedances account for similar proportions of consecutive exceedances across all UK regions; there are negligible differences between regions. The regions that see the

Page $7 / 30$ 
smallest proportions of successive 1 in 1-year still sea level exceedances occurring within 365 days of the previous exceedance are the North Sea and English Channel.The Bristol Channel and North Atlantic see the highest proportions occurring within 365 days of the prior exceedance. Both regions see over half of still sea level exceedances occurring within 50 days of the last exceedance. At the higher 1 in 5 -year return level, the North Sea sees the smallest proportions of exceedances occurring within 365 days of the previous exceedance for both still sea level and surge parameters. Only 21\% of still sea level exceedances and $17 \%$ of surge exceedancesoccur within 365 days of the prior exceedance. The Bristol Channel has the highest proportions for the two parameters. Despite no 1 in 5-year still sea level exceedances occurring in the Bristol Channel within 14 days of each other, $\sim 60 \%$ occur within 365 days of the last. Conversely, the Bristol Channel has a high proportion of 1 in 5-year surge exceedances occurring within 14 days of each other ( $17 \%)$.North Atlantic gauges have no still sea levelexceedances occurring within3-14 or 50-100 days of the last. Nevertheless, the North Atlantic still has the second highest proportion of exceedances ( 33\%) occurring within 365 days of the prior exceedance. The North Atlantic has a higher percentage ( 21\%) of 1 in 5 -year surge exceedances occurring within 14 days of the previous exceedance than the North Sea hasexceedances occurring within 365 days of the last ( 17\%), yetNorth Atlantic gauges record no instances of a 1 in 5-year surge exceedance occurring within either 14-50 days or 50-100 days of the previous exceedance.

The percentage of consecutive exceedances at the six specified timescales are shown in Figure 10 for significant wave height; as the CCO data is only for England, the data is averaged across the sites in five main English regions (Figures 10a-e, the regions are shown in Figure 1b) and again for all sites (Figure 10f). The results must be approached with some caution, as some regions have a low number of sites, and the overall wave record length is short. However, for the measured exceedances, the North Sea has by far the highest percentage ( 20\%) of 1 in 1-year exceedances occurring $<1-3$ days after the previous exceedance,when compared to the other English regions. The other regionssee $\sim 14-21 \%$ of consecutive exceedances occurring within 14 days of the previous - except for the Irish Sea which only experiences $\sim 4 \%$ of exceedances in<1-3 days of the prior exceedance and no exceedances within 3-14 days. At the 1 in 5year return level, the differences become starker as the greater rarity of these exceedances combine with the short records. The Irish Sea sees no exceedances within 14 days of the previous exceedance, the Celtic Sea has no exceedances within 50 days of the prior, and the Bristol Channel has no exceedances within 100 days of the prior. 5 ( 11\%) of North Sea 1 in 5-year return level exceedances occur within 3 (14) days of the previous exceedance, whereas the English Channel sees no exceedances within 3 days of the previous exceedance but has $18 \%$ occurring within 14 days.

\section{Discussion}

We haveused measuredand modelled still sea level and wave data to quantify the prevalence of storm clustering around the UKin surges, waves and still sea levelson two timescales, interseasonal and intraseasonal.

First,we analysed interseasonal clustering around the UK and show that all parameters have consecutive seasons that contain high counts of exceedances, as well as consecutive seasons that contain low counts of exceedances. There are seasons where significantly more exceedancesare found than in other seasons. These periods of varying counts of exceedances are likely linked to changes in large-scale ocean-atmospheric patterns such as the North Atlantic Oscillation (NAO) or West Europe Pressure Anomaly (WEPA), that have been shown to affect UK storm surges and waves (e.g., Woodworth et al. 2007; Castelleet al. 2017; Santos et al. 2017).Importantly, there are seasons wherenumerous exceedances at the 1 in 1-year return level do not see a closely matched signal atthe 1 in 5-year return level. The clustering of lower-magnitude exceedances could be of interest to future research into beach recovery mechanisms as energetic winter wave conditions have been shown to be essential in morphological recovery at certain beaches whilst stall recovery at others (Scott et al.2016; Dodetet al.2018).

There is a level of spatial coherence for exceedances shownamong regions around the coast - if a site experiences a storm surge, wave height, or still sea levelexceedance in a season, it is likely that neighbouring sites in that region will also experience an exceedance in that season. This spatial coherence supports other research that has identified broad regional footprints of storm events (Haigh et al. 2016). These findings advocate the utility of regional-scale resilience planning for not only singular storm events, but for entire winter storm seasons as multiple exceedances are seen across regional scales within seasons and across multi-season periods.Future research analysing the influence of ocean-atmosphere patterns to the interseasonal clustering shown in this research may further aid in forecast-based resilience planning.

A key finding is thatsignificant proportions of storm surge, wave heightand still sea level exceedancesare clustering onintraseasonal timescales.As expected, exceedances of a lower-magnitude cluster more than those of a higher-magnitude.Storm surge exceedances occurring within 50 days of the previous exceedance account for $\sim 40 \%(\sim 15 \%)$ of exceedances at or above the 1 in 1- (5-) year return level.Despite our smaller storm window,our similar analysis to Santos et al. (2017)resulted in lower proportions of 1 in 1-year wave height exceedances occurring within 4, 8, and 20 days of the last event. A similar proportion of wave exceedances occurred within 4 days of the previous event ( 12\% compared to 16\%), but we find only 22\% occurring within 20 days compared with Santos et al.'s (2017) 50\%.In contrast, we identify significantly more clustering in still sea levels than Haigh et al. (2016). With our updated data record, we find 32 pairs of still sea levels that exceed the 1 in 5-year return level whilst Haighet al. (2016) found 7; although, note Haigh et al. (2016) focused on events across sites, whereas we focus on individual sites, so a direct comparison is not possible. We find that still sea levels cluster more than storm surges and waves, with a $25 \%$ ( 9) of all consecutive 1 in 1- (5-) year still sea level exceedances occurring within 4 days of the last and $~ 83 \%$ ( $78 \%$ ) of these exceedances occurring within 2 days. At both return levels, over half of all still sea level exceedances occurring within 28 days of the prior exceedance occur within 2 days. These quick-succession exceedances are likely to be a result of astronomical high tides either exceeding the threshold or raising the still sea level enough so that lower-magnitude storm surges raise the sea levels above critical thresholds. This can be seen in the far higher number of 1 in 1 -year storm surge exceedances occurring within 2 days of the last (123 pairs) compared to the 1 in -5 year ( 2 pairs).

Our analysis shows that storm surgeexceedancesare not concurrent with still sea level exceedances. As discussed above, this isexpected ashigh still sea levels are driven primarily by high spring tides and moderate, rather than extreme, surges (Haigh et al. 2016). The spring/neap tidal cycle was shown in Haigh et al. (2016) to prevent consecutive 1 in 5-year still sea level events occurring within 4-8 days of each other as one would always fall on neap tide. This tidal cycle leads to many 'misses' where extreme surge events do not see corresponding extreme still sea levels as the combined sea level is not raised high 
enough. Wefound only one instance of 1 in 5-year still sea level exceedancesoccurring within 4-8 days of each other,but we did find 291 in 1 -year still sea level exceedances occurring in this window. These represent particularly extreme surge events that raise still sea levels above the 1 in 1 -year return level even at neap tide.

Our comparison between the measured and modelled datasets illustrated some of the important problems associated with using modelled hindcasts for the analysis of extremes. There are significant challenges in accurately modelling extreme events (Sillmannet al. 2017) and any model will inherit the uncertainties associated with the forcing. The modelled datasets used here accurately represented the general statistics of the measured data (as illustrated by the good level of validation; see Muis et al. 2020) but, as we show here, they do not capture some of the seasonal signals and patterns in the exceedance levels. For instance, it is unclear why the stormiest season on record (2013/14) was not characterised to the same extent in the modelled data. Nevertheless, hindcasts are the only method of gaining gap-free continuousdata around the coast (and at ungauged sites), which is particularly important considering the short data lengths of UK wave buoys.

Studies have recently investigated the atmospheric conditions responsible for the clustering of midlatitude storms (e.g., Pinto et al. 2014; Priestley et al. 2017a; Priestley et al. 2020). The clustering of storms at seasonal timescales is linked to large-scale atmospheric patterns whereas the clustering of storms in quicker succession is associated with secondary cyclogenesis (Dacre and Pinto, 2020). These atmospheric mechanisms shown to promote the clustering of intense storms combined in 2013/14 to propagate a sequence of cyclones towards western Europe (Priestley et al. 2017b). This season was the stormiest on record (Matthews et al. 2014) and saw widespread coastal flooding due to extreme sea levels and waves (Haigh et al. 2016). Our results reaffirm this, with the season's high number of exceedances and large spatial footprint being unmatched across all measured parameters.

The studies mentioned above examining the atmospheric mechanisms of clustering have focused on the clustering of the most intense storms. As mentioned however, the vast majority of UK sea level exceedances at the 1 in 5-year return level are caused by moderate, rather than extreme, skew surge events that occurat high spring tides (Haigh et al. 2016). This combined with the significant levels of clustering at the lower 1 in 1-year return level shown in this research suggests that future study exploring the clustering of less-intense storms would be of interest. Our analysis presents many suitable case study seasons where large parts of the UK experienced elevated counts of 1 in 1-year still sea level exceedances without also seeing many 1 in 5-year exceedances. For example, 2006/07 recorded 149 still sea levels at or above the 1 in 1-year level, but only 15 of those still sea levels were at or above the higher 1 in 5 -year level.

A key limitation of our study is the lack of data availability through time. This is a common problem for the research of extreme natural hazards, but it is compounded in clustering research due to the further rarity of the phenomenon. Wave data is mainly limited to the last decade and any analysis further back in time relies on modelled hindcasts. The varying data lengths of tide gauges also presents the possibility of data bias when analysing the days between consecutive exceedances. Repeating the intraseasonal(days between) analysis for tide gauge sites with $>30$ years of data produces similar results to that of all sites (see SupplementaryFigure S5). This indicates that the results are not being significantly biased by sites with short data lengths and present an adequate portrayal of extremes through time. As the wave sites have far shorter data lengths, an element of data bias must be considered in wave height results. The use of non-English wave buoys would improve this research, but wave buoys found in other parts of the UK (such as WaveNet's) are mainly further offshore and therefore unsuitable for this research. Although we havea higher density of sites for English regions when compared to the tide gauge network, we are missing key UK regions. For example, there are no wave sites in the North Atlantic and on the northern coastline of the Bristol Channel- two important regions of clustering identified from the still sea level and surge analysis.

This analysis focused on the primary parameters of use for coastal flooding (storm surge and significant wave height) and also consideredstill sea level. Other parameters, such as long period swell waves and total water level, also directly affect coastal flooding (e.g., Sibley and Cox, 2014) and knowledge into how these cluster across the UK would be of interest. The ERA5 wave hindcast contains wave swell and could also be used to create a novel dataset of total water level far longer than is possible with measured wave data. This extended dataset of total water levels around the UK coastline will be of particular interest as wave-induced water levels represent the maximum potential hazard from the compound effects of sea levels and waves.

We have shown that the clustering of storm surge, wave, and still sea level exceedances is a feature of the UK recordsand is therefore important for coastal stakeholders to consider. An initial storm may not cause flooding but the weakening of coastal defences or the erosion of beach sediment may allow a successive, possibly weaker storm, to cause flooding. This is of particular importance in areas of ageing coastal defences, whereby the compounded loading on the defences is more likely to lead to failure. Storms clustering in quick succession will require storm surge barriers to be closed repeatedly, requiring high levels of maintenance in short time periods. Multiple flooding events in a season also require high levels of human effort from emergency responders to deal with damages and threat to life. Consecutive flooding will place strains on temporary defences and pumping systems assembled for the initial flood event. Such hazards cause widespread economic damages and present a major cause of loss for the insurance industry. The clustering of storms affects probability of occurrence assessments and aggregate loss calculations, with insurers seeing significant pay-outs multiple times in a season. The mental health impacts from flooding hazards have also been shown to be as important as physical illness impacts, with the memory and frequency of flooding relating to possible higher levels of emotional distress (Lamond, 2014). Action to limit the severity of flooding in the successive flood is difficult when storms cluster in quick succession. This could have a negative effect on trauma levels and mental health outcomes for the affected populations.

\section{Conclusions}

In this paper we assessed the temporal characteristics of the clustering of storm surges, waves and high still sea levels around the UK coastline. We identified exceedances at or above the 1 in 1- and 5-year return level on two timescales, interseasonal and intraseasonal.

We first addressed objective 1, characterising the clustering of highstill sea levels, storm surges and waveson the interseasonal timescale. We used seasonal counts of exceedances to identify seasonal clustering across the timeseries and the spatial footprint of clustered periods. We compared measured datasets to modelled hindcast datasets and highlighted the issues surrounding using modelled data for the analysis ofstorm clustering. Exceedances are not consistent

Page 9/30 
through time and there are significant periods with and without exceedances, at our two chosen thresholds. There is a level of spatial coherence between sites around different regions of the UK with elevated seasonal counts of exceedances frequently occur across neighbouring sitesin a given region. This is important to account for when assessing the risk of events aggregated at large scales, for example to inform insurance industry resilience or national emergency preparedness. The 2013/14 season is the most extreme season on record, with exceptional high counts across all parameters at both the 1 in 1 and 5-year return levels. Some seasons, such as 2006/07, also sawhigh numbers of exceedances at the lower 1 in 1 -year return level without a matching high signal at the 1 in 5 -year level.

We then addressed objective 2, characterising the clustering of high still sea levels, storm surges and waves on the intraseasonal timescale. We examined the number of days between consecutive exceedances to quantify the proportion of exceedances that cluster over varying timescales within a season. We compared this between regions to classify differences between the levels of clustering around the UK coast.A key finding is that within seasons containing multiple exceedances, significant proportions of these occur in quick succession;Storm surge, wave and still sea levelexceedances occurring within 50 days of the previous exceedanceaccount for $\sim 35-44 \%$ ( 15-22\%) of exceedances at or above the 1 in 1- (5-) year return level. The clustering of storms is apparent in all regions of the UK but is more prevalent in the North Atlantic and Bristol Channel, and less prevalent in the North Sea.

The findings of this research can be used to aid the prediction and management of coastal flooding risks due to the sequencing of storm surges, waves, and high still sea levels. The clustering of storms in quick succession can amplify damages when the temporal succession is less than the recovery times of various elements of the natural and human coastal defence system. We show that it is likely coastal communitiesmay face multiple storm surge, wave and still sea level exceedances in stormy seasons, and that neighbouring regions are also likely to experience thisas well during that season. This has many implications for coastal stakeholders, as emergency responderscan more effectively plan for storm events. The timescales on which storm surges, waves and still sea levels cluster illuminate the potential benefitsof fast action after an initial storm. This action could be for the repairs of storm surge barriers and coastal defences, or the pumping of flood waters and placement of temporary defences. Fast, effective action may be crucial in mitigating storm damages when they cluster in quick succession.

\section{Declarations}

Funding: LJJ is funded through the INSPIRE Doctoral Training Partnershipby the Natural Environment Research Council (NERC) (NE/S007210/1), and cosponsored by the JBA Trust. IDH and PC's time was funded via the NERC funded CHANCE project (NE/S010262/1).

Competing Interests: The authors have no competing interests to declare.

Author Contributions: Data collection and processing was undertaken by LJJ, IDH and PC. The analysis was carried out by LJJ and IDH. LJJ wrote the initial version of the manuscript. All authors reviewed and commented on the methodology and manuscript.

Acknowledgements: We would like to thank the British Oceanographic Data Centre (BODC), Channel Coast Observatory (CCO) and Environment Agency (EA) for providing sea level, wave, and return level statisticsdata used in this research.

\section{References}

1. Batstone, C et al. (2013). A UK best-practice approach for extreme sea-level analysis along complex topographic coastlines, Ocean Engineering, 71:2839.https://doi.org/10.1016/j.oceaneng.2013.02.003

2. Bouwer, LM and Jonkman, SN (2018). Global mortality from storm surges is decreasing, Environmental Research Letters, 13:014008.https://doi.org/10.1088/1748-9326/aa98a3

3. Castelle, B et al. (2017). A new climate index controlling winter wave activity along the Atlantic coast of Europe: The West Europe Pressure Anomaly, Geophys Res Lett, 44:1384-1392.https://doi.org/10.1002/2016gl072379

4. Codiga, D (2021). UTide Unified Tidal Analysis and Prediction Functions, MATLAB Central File Exchange. Accessed from: https://www.mathworks.com/matlabcentral/fileexchange/46523-utide-unified-tidal-analysis-and-prediction-functions

5. Dacre, HF and Pinto, JG (2020). Serial clustering of extratropical cyclones: a review of where, when and why it occurs, npj Climate and Atmospheric Science, 3:48.https://doi.org/10.1038/s41612-020-00152-9

6. Dangendorf, S et al. (2017). Reassessment of 20th century global mean sea level rise, P Natl Acad Sci USA, 114:5946-

5951.https://doi.org/10.1073/pnas.1616007114

7. Dodet, G et al. (2018). Beach recovery from extreme storm activity during the 2013-14 winter along the Atlantic coast of Europe, Earth Surf Proc Land, 44:393-401.https://doi.org/10.1002/esp.4500

8. Dhoop, T and Mason, T (2018). Spatial Characteristics and Duration of Extreme Wave Events around the English Coastline, J Mar Sci Eng, 6 (1):14.https://doi.org/10.3390/jmse6010014

9. Dhoop, T and Thompson, C (2018). Extreme Value Analysis for CCO Coastal Wave Data. TN03., Southampton: Channel Coastal Observatory, 1-11. Accessed from: https://coastalmonitoring.org/reports/

10. Dissanayake, P et al. (2015). Comparison of storm cluster vs isolated event impacts on beach/dune morphodynamics, Estuar Coast Shelf S, 164:301312.https://doi.org/10.1016/j.ecss.2015.07.040

Page $10 / 30$ 
11. Fox-Kemper, B et al. (2021). Ocean, Cryosphere and Sea Level Change, In: Masson-Delmotte, V et al.(eds.) Climate Change 2021: The Physical 12 Science Basis. Contribution of Working Group I to the Sixth Assessment Report of the Intergovernmental Panel on Climate Change. Cambridge: Cambridge University Press.

12. Garner, AJ et al. (2018). Evolution of 21st Century Sea Level Rise Projections, Earths Future, 6:1603-1615.https://doi.org/10.1029/2018ef000991

13. Godoi, VA, Bryan, KR and Gorman, RM (2018). Storm wave clustering around New Zealand and its connection to climatic patterns, Int J Climatol, 38:e401e417.https://doi.org/10.1002/joc.5380

14. Haigh, IDH, Eliot, M and Pattiaratchi, C (2011). Global influences of the 18.61 year nodal cycle and 8.85 year cycle of lunar perigee on high tidal levels, Journal of Geophysical Research: Oceans, 116:C06025.https://doi.org/10.1029/2010JC006645

15. Haigh, IDH et al. (2015). A user-friendly database of coastal flooding in the United Kingdom, Sci Data, 2:150021.https://doi.org/10.1038/sdata.2015.21

16. Haigh, IDHet al. (2016). Analysis: Spatial and temporal analysis of extreme sea level and storm surge events around the coastline of the UK, Sci Data, 3:160107.https://doi.org/10.1038/sdata.2016.107

17. Haigh, IDH, Nicholls, RJ and Wells, NC (2009). Mean sea-level trends around the English Channel over the 20th century and their wider context, Cont Shelf Res, 29:2083-2098.https://doi.org/10.1016/j.csr.2009.07.013

18. Hallegatte, S et al. (2013). Future flood losses in major coastal cities, Nature Climate Change, 3 (9):902-906.https://doi.org/10.1038/NCLIMATE1979

19. Hersbach, $\mathrm{H}$ et al. (2020). The ERA5 global reanalysis, Quarterly Journal of the Royal Meteorological Society, 146 (730):19992049.https://doi.org/10.1002/qj.3803

20. Hinkel, J et al. (2014). Coastal flood damage and adaptation costs under $21^{\text {st }}$ century sea-level rise, Proc Natl Acad Sci U.S.A., 111 (9):32923297.https://doi.org/10.1073/pnas.1222469111

21. Hogarth, P et al. (2021). Changes in mean sea level around Great Britain over the past 200 years, Progress in Oceanography, 192:102521.https://doi.org/10.1016/j.pocean.2021.102521

22. Karunarathna, $\mathrm{H}$ et al. (2013). The effects of storm clustering on beach profile variability, Marin Geology, 348:103112.https://doi.org/10.1016/j.margeo.2013.12.007

23. Kulp, SA and Strauss, BH (2019). New elevation data triple estimates of global vulnerability to sea-level rise and coastal flooding, Nature Communications, 10:4844.https://doi.org/10.1038/s41467-019-12808-z

24. Lamond, J (2014). The role of flood memory in the impact of repeat flooding on mental health, In:Proverbs,D andBrebbia, C,(eds.) Flood Recovery, Innovation and Response, Southampton: IVWIT Press.

25. Luijendijk, A et al. (2018). The State of the World's Beaches, Scientific Reports, 8:6641.https://doi.org/10.1038/s41598-018-24630-6

26. Masselink, G et al. (2020). Impacts of climate change on coastal geomorphology and coastal erosion relevant to the coastal and marine environment around the UK, MCCIP Science Review 2020, 158-489. https://doi: 10.14465/2020.arc08.cgm

27. Matthews, T et al. (2014). Stormiest winter on record for Ireland and UK, Nature Climate Change, 4:738-740.https://doi.org/10.1038/nclimate2336

28. Muis, S et al. (2020). A High-Resolution Global Dataset of Extreme Sea Levels, Tides, and Storm Surges, Including Future Projections, Front Mar Sci, 7:263.https://doi.org/10.3389/fmars.2020.00263

29. Nerem, RS et al. (2018). Climate-change-driven accelerated sea-level rise detected in the altimeter era, P Natl Acad Sci USA, 115:20222025.https://doi.org/10.1073/pnas.1717312115

30. Office for National Statistics, (2020). Coastal towns in England and Wales: October 2020.

31. Pinto, JG et al. (2014). Large-scale dynamics associated with clustering of extratropical cyclones affecting Western Europe, Journal of Geophysical Research: Atmospheres, 119 (13):704-13,719.https://doi.org/10.1002/2014jd022305

32. Priestley, MDK et al. (2017a). Rossby wave breaking, the upper level jet, and serial clustering of extratropical cyclones in western Europe, Geophys Res Lett, 44:514-521.https://doi.org/10.1002/2016gl071277

33. Priestley, MDK et al. (2017b). The role of cyclone clustering during the stormy winter of 2013/2014, Weather, 72:187-192. https://doi.org/10.1002/wea.3025

34. Priestley, MDK et al. (2020). The role of secondary cyclones and cyclone families for the North Atlantic storm track and clustering over western Europe, Q J Roy Meteor Soc, 146:1184-1205.https://doi.org/10.1002/qj.3733

35. Santos, VM, Haigh, IDH and Wahl, T (2017). Spatial and Temporal Clustering Analysis of Extreme Wave Events around the UK Coastline, J Mar Sci Eng, 5(3):28.https://doi.org/10.3390/jmse5030028

36. Sayers, PB et al. (2015). Climate Change Risk Assessment 2017: Projections of future flood risk in the UK, Sayers and Partners LLP Report for the Committee on Climate Change, 1-125, Accessed from: https://www.theccc.org.uk/wp-content/uploads/2015/10/CCRA-Future-Flooding-Main-Report-Final060ct2015.pdf

37. Scott, Tet al. (2016). The extreme 2013/2014 winter storms: Beach recovery along the southwest coast of England, Marine Geology, 382:224241.https://doi.org/10.1016/j.margeo.2016.10.011

38. Spencer, T et al. (2015). Southern North Sea storm surge event of 5 December 2013: Water levels, waves and coastal impacts, Earth-Science Reviews, 146:120-145.https://doi.org/10.1016/j.earscirev.2015.04.002

39. Stephens, SA, Bell, RG and Haigh, IDH (2020). Spatial and temporal analysis of extreme storm-tide and skew-surge events around the coastline of New Zealand, Nat Hazards Earth Syst Sci, 20:783-796.https://doi.org/10.5194/nhess-20-783-2020

40. Vousdoukas, Ml et al. (2020). Sandy coastlines under threat of erosion, Nature Climate Change, 10:260-263.https://doi.org/10.1038/s41558-020-0697-0

Page $11 / 30$ 
41. Wadey, MP, Haigh, IDH and Brown, JM (2014). A century of sea level data and the UK's 2013/14 storm surges: an assessment of extremes and clustering using the Newlyn tide gauge record, Ocean Sci, 10:1031-1045.https://doi.org/10.5194/os-10-1031-2014

42. Woodworth, PL et al. (2007). The dependence of UK extreme sea levels and storm surges on the North Atlantic Oscillation, Continental Shelf Research, 27:935-946.https://doi.org/10.1016/j.csr.2006.12.007

43. Woodworth, PL et al. (2009). Trends in UK mean sea level revisited, Geophys J Int, 176:19-30.https://doi.org/10.1111/j.1365-246X.2008.03942.x

\section{Tables}

Table 1: Information on the EA tide gauge study sites and the statistics of 1 in 1-year sea level and storm surge exceedances at each site. 


\begin{tabular}{|c|c|c|c|c|c|c|c|c|c|c|c|}
\hline Study site & Longitude & Latitude & $\begin{array}{l}\text { Nearest } \\
\text { CODEC } \\
\text { grid node } \\
\text { longitude }\end{array}$ & $\begin{array}{l}\text { Nearest } \\
\text { CODEC } \\
\text { grid } \\
\text { node } \\
\text { latitude }\end{array}$ & $\begin{array}{l}\text { Data } \\
\text { length }\end{array}$ & $\begin{array}{l}\text { Data } \\
\text { coverage } \\
(\%)\end{array}$ & $\begin{array}{l}\text { Exceedance } \\
\text { count }\end{array}$ & $\begin{array}{l}\text { Number of } \\
\text { seasons } \\
\text { with } \\
\text { exceedances }\end{array}$ & $\begin{array}{l}\text { Min. number } \\
\text { of days } \\
\text { between } \\
\text { exceedances }\end{array}$ & $\begin{array}{l}\text { Max. } \\
\text { number of } \\
\text { days } \\
\text { between } \\
\text { exceedances }\end{array}$ & $\begin{array}{l}\text { Avg } \\
\text { of d } \\
\text { betv } \\
\text { exc1 }\end{array}$ \\
\hline $\begin{array}{l}\text { All Sites } \\
\text { (average) }\end{array}$ & & & & & $\begin{array}{l}45 \mathrm{y} \\
7 \mathrm{mo}\end{array}$ & 81.3 & 47.2 & 25.3 & 1.4 & 2259.4 & 319 \\
\hline Lerwick & -1.14 & 60.15 & -1.12 & 60.10 & $\begin{array}{l}62 \mathrm{y} \\
6 \mathrm{mo}\end{array}$ & 78.5 & 48 & 24 & 1 & 4621 & 390 \\
\hline Wick & -3.09 & 58.44 & -3.05 & 58.47 & $\begin{array}{l}56 \mathrm{y} \\
6 \mathrm{mo}\end{array}$ & 91.8 & 30 & 19 & 0.7 & 1482.6 & 322 \\
\hline Moray Firth & -4.00 & 57.60 & -4.02 & 57.63 & $\begin{array}{l}10 \mathrm{y} \\
11 \mathrm{mo}\end{array}$ & 74.6 & 22 & 13 & 1.3 & 667.1 & 225 \\
\hline Aberdeen & -2.08 & 57.14 & -2.06 & 57.17 & $\begin{array}{l}91 \mathrm{y} \\
6 \mathrm{mo}\end{array}$ & 74.6 & 35 & 21 & 1 & 1911.3 & 345 \\
\hline Leith & -3.18 & 55.99 & -3.20 & 55.99 & $\begin{array}{l}40 \mathrm{y} \\
6 \mathrm{mo}\end{array}$ & 85.7 & 95 & 49 & 0.8 & 6996 & 361 \\
\hline North Shields & -1.44 & 55.01 & -1.43 & 55.04 & $\begin{array}{l}75 \mathrm{y} \\
6 \mathrm{mo}\end{array}$ & 82.7 & 32 & 18 & 1 & 2130 & 342 \\
\hline Whitby & -0.61 & 54.49 & -0.59 & 54.49 & $\begin{array}{l}41 \mathrm{y} \\
6 \mathrm{mo}\end{array}$ & 81.5 & 52 & 26 & 1 & 2482.2 & 370 \\
\hline Immingham & -0.19 & 53.63 & -0.07 & 53.81 & $\begin{array}{l}68 \mathrm{y} \\
6 \mathrm{mo}\end{array}$ & 81.8 & 37 & 25 & 1 & 1180.7 & 387 \\
\hline Cromer & 1.30 & 52.93 & 1.33 & 52.92 & $\begin{array}{l}48 \mathrm{y} \\
6 \mathrm{mo}\end{array}$ & 79.0 & 112 & 55 & 0.7 & 2187.8 & 337 \\
\hline Lowestoft & 1.75 & 52.47 & 1.75 & 52.45 & $\begin{array}{l}57 \mathrm{y} \\
6 \mathrm{mo}\end{array}$ & 95.8 & 45 & 17 & 0.7 & 1511.3 & 208 \\
\hline Felixstowe & 1.35 & 51.96 & 1.38 & 51.98 & $\begin{array}{l}29 \mathrm{y} \\
11 \mathrm{mo}\end{array}$ & 85.6 & 27 & 17 & 1 & 1742.9 & 399 \\
\hline Harwich & 1.29 & 51.95 & 1.31 & 51.92 & $\begin{array}{l}67 \mathrm{y} \\
6 \mathrm{mo}\end{array}$ & 78.9 & 29 & 16 & 1.9 & 2099.7 & 337 \\
\hline Sheerness & 0.74 & 51.45 & 0.74 & 51.50 & $\begin{array}{l}69 \mathrm{y} \\
6 \mathrm{mo}\end{array}$ & 62.4 & 60 & 37 & 1.2 & 2189.2 & 334 \\
\hline Dover & 1.32 & 51.11 & 1.31 & 51.12 & $\begin{array}{l}97 y \\
6 \mathrm{mo}\end{array}$ & 76.3 & 51 & 24 & 0.8 & 776.3 & 196 \\
\hline Newhaven & 0.06 & 50.78 & 0.02 & 50.78 & $\begin{array}{l}39 \mathrm{y} \\
6 \mathrm{mo}\end{array}$ & 95.0 & 30 & 18 & 1.7 & 1593 & 318 \\
\hline Portsmouth & -1.11 & 50.80 & -1.09 & 50.74 & $\begin{array}{l}30 \mathrm{y} \\
6 \mathrm{mo}\end{array}$ & 92.6 & 66 & 40 & 1.6 & 2871.2 & 366 \\
\hline Bournemouth & -1.87 & 50.71 & -1.90 & 50.71 & $\begin{array}{l}25 \mathrm{y} \\
6 \mathrm{mo}\end{array}$ & 67.2 & 56 & 41 & 0.8 & 1487 & 372 \\
\hline St. Helier & -2.12 & 49.18 & -2.09 & 49.17 & $\begin{array}{l}29 y \\
6 \mathrm{mo}\end{array}$ & 85.1 & 79 & 46 & 1.6 & 1708.2 & 310 \\
\hline Weymouth & -2.45 & 50.61 & -2.47 & 50.57 & $\begin{array}{l}30 \mathrm{y} \\
6 \mathrm{mo}\end{array}$ & 82.1 & 79 & 35 & 0.9 & 3234.7 & 308 \\
\hline Devonport & -4.19 & 50.37 & -4.18 & 50.33 & $\begin{array}{l}34 \mathrm{y} \\
6 \mathrm{mo}\end{array}$ & 89.8 & 42 & 30 & 1.7 & 1458.3 & 350 \\
\hline Newlyn & -5.54 & 50.10 & -5.50 & 50.11 & $\begin{array}{l}106 y \\
6 \mathrm{mo}\end{array}$ & 88.2 & 32 & 20 & 6.4 & 1039.6 & 284 \\
\hline St. Marys & -6.32 & 49.92 & -5.71 & 50.11 & $\begin{array}{l}45 \mathrm{y} \\
6 \mathrm{mo}\end{array}$ & 67.5 & 31 & 22 & 3.5 & 1071.5 & 330 \\
\hline Ilfracombe & -4.11 & 51.21 & -4.08 & 51.22 & $\begin{array}{l}53 y \\
6 \mathrm{mo}\end{array}$ & 79.1 & 33 & 17 & 1.1 & 1470 & 262 \\
\hline Hinkley Point & -3.13 & 51.22 & -3.10 & 51.20 & $\begin{array}{l}31 \mathrm{y} \\
6 \mathrm{mo}\end{array}$ & 86.3 & 32 & 15 & 0.9 & 1497.9 & 268 \\
\hline Portbury & -2.73 & 51.50 & -2.81 & 51.51 & $\begin{array}{l}13 \mathrm{y} \\
6 \mathrm{mo}\end{array}$ & 48.4 & 60 & 33 & 0.8 & 2126.4 & 354 \\
\hline Avonmouth & -2.71 & 51.51 & -2.81 & 51.51 & $\begin{array}{l}51 \mathrm{y} \\
3 \mathrm{mo}\end{array}$ & 79.1 & 59 & 33 & 1.6 & 4713 & 348 \\
\hline
\end{tabular}




\begin{tabular}{|c|c|c|c|c|c|c|c|c|c|c|c|}
\hline Newport & -2.99 & 51.55 & -2.97 & 51.54 & $\begin{array}{l}28 \mathrm{y} \\
6 \mathrm{mo}\end{array}$ & 73.1 & 67 & 31 & 0.8 & 2557.6 & 316 \\
\hline Mumbles & -3.98 & 51.57 & -3.99 & 51.57 & $\begin{array}{l}32 \mathrm{y} \\
11 \mathrm{mo}\end{array}$ & 61.2 & 33 & 15 & 0.8 & 1809.2 & 283 \\
\hline $\begin{array}{l}\text { Milford } \\
\text { Haven }\end{array}$ & -5.05 & 51.71 & -5.08 & 51.66 & $\begin{array}{l}68 \mathrm{y} \\
6 \mathrm{mo}\end{array}$ & 79.8 & 29 & 14 & 1 & 2627.4 & 342 \\
\hline Fishguard & -4.98 & 52.01 & -4.97 & 52.02 & $\begin{array}{l}58 \mathrm{y} \\
6 \mathrm{mo}\end{array}$ & 84.9 & 103 & 48 & 1.1 & 3302.8 & 318 \\
\hline Barmouth & -4.05 & 52.72 & -4.07 & 52.71 & $\begin{array}{l}30 \mathrm{y} \\
6 \mathrm{mo}\end{array}$ & 65.5 & 28 & 15 & 1.4 & 1809.7 & 350 \\
\hline Holyhead & -4.62 & 53.31 & -4.62 & 53.27 & $\begin{array}{l}57 y \\
6 \mathrm{mo}\end{array}$ & 86.2 & 44 & 23 & 1.4 & 1556.3 & 269 \\
\hline Llandudno & -3.83 & 53.33 & -3.79 & 53.31 & $\begin{array}{l}50 \mathrm{y} \\
6 \mathrm{mo}\end{array}$ & 87.4 & 71 & 35 & 0.7 & 2449.6 & 308 \\
\hline Liverpool & -3.02 & 53.45 & -3.07 & 53.49 & $\begin{array}{l}30 \mathrm{y} \\
6 \mathrm{mo}\end{array}$ & 80.4 & 46 & 26 & 2.1 & 1143.4 & 300 \\
\hline Heysham & -2.92 & 54.03 & -2.91 & 54.05 & $\begin{array}{l}57 y \\
6 \mathrm{mo}\end{array}$ & 80.2 & 7 & 4 & 1.9 & 770.3 & 309 \\
\hline Port Erin & -4.77 & 54.09 & -4.75 & 54.06 & $\begin{array}{l}29 y \\
6 \mathrm{mo}\end{array}$ & 93.9 & 35 & 15 & 0.9 & 4773.8 & 332 \\
\hline Workington & -3.57 & 54.65 & -3.57 & 54.66 & $\begin{array}{l}29 y \\
6 \mathrm{mo}\end{array}$ & 95.3 & 61 & 33 & 1.8 & 1797.8 & 307 \\
\hline Bangor & -5.67 & 54.66 & -5.68 & 54.69 & $\begin{array}{l}26 y \\
8 \mathrm{mo}\end{array}$ & 68.1 & 49 & 25 & 0.7 & 2216.3 & 335 \\
\hline Portpatrick & -5.12 & 54.84 & -5.12 & 54.84 & $\begin{array}{l}53 \mathrm{y} \\
6 \mathrm{mo}\end{array}$ & 85.7 & 32 & 18 & 3 & 1473.4 & 351 \\
\hline Portrush & -6.66 & 55.21 & -6.63 & 55.22 & $\begin{array}{l}26 y \\
6 \mathrm{mo}\end{array}$ & 86.6 & 46 & 26 & 1.4 & 2212.8 & 390 \\
\hline Port Ellen & -6.19 & 55.63 & -6.20 & 55.61 & $\begin{array}{l}32 \mathrm{y} \\
11 \mathrm{mo}\end{array}$ & 93.1 & 51 & 31 & 0.7 & 1875.5 & 401 \\
\hline Millport & -4.91 & 55.75 & -4.93 & 55.70 & $\begin{array}{l}43 y \\
6 \mathrm{mo}\end{array}$ & 83.9 & 31 & 15 & 1.6 & 1075.3 & 233 \\
\hline Tobermory & -6.06 & 56.62 & -6.10 & 56.76 & $\begin{array}{l}31 y \\
6 m o\end{array}$ & 87.7 & 30 & 18 & 1.6 & 1824.6 & 292 \\
\hline Ullapool & -5.16 & 57.90 & -5.37 & 57.96 & $\begin{array}{l}55 \mathrm{y} \\
6 \mathrm{mo}\end{array}$ & 84.4 & 72 & 29 & 1.5 & 10522.8 & 341 \\
\hline Stornoway & -6.39 & 58.21 & -6.32 & 58.17 & $\begin{array}{l}45 \mathrm{y} \\
6 \mathrm{mo}\end{array}$ & 84.5 & 49 & 23 & 0.7 & 803.8 & 191 \\
\hline Kinlochbervie & -5.05 & 58.46 & -5.12 & 58.48 & $\begin{array}{l}30 \mathrm{y} \\
6 \mathrm{mo}\end{array}$ & 86.4 & 12 & 7 & 0.9 & 1080.6 & 290 \\
\hline
\end{tabular}

Table 2: Information on the EA tide gauge study sites and the statistics of 1 in 5-year sea level and storm surge exceedances at each site. 


\begin{tabular}{|c|c|c|c|c|c|c|c|c|c|c|c|}
\hline Study site & Longitude & Latitude & $\begin{array}{l}\text { Nearest } \\
\text { CODEC } \\
\text { grid node } \\
\text { longitude }\end{array}$ & $\begin{array}{l}\text { Nearest } \\
\text { CODEC } \\
\text { grid } \\
\text { node } \\
\text { latitude }\end{array}$ & $\begin{array}{l}\text { Data } \\
\text { length }\end{array}$ & $\begin{array}{l}\text { Data } \\
\text { coverage } \\
\text { (\%) }\end{array}$ & $\begin{array}{l}\text { Exceedance } \\
\text { count }\end{array}$ & $\begin{array}{l}\text { Number of } \\
\text { seasons } \\
\text { with } \\
\text { exceedances }\end{array}$ & $\begin{array}{l}\text { Min. number } \\
\text { of days } \\
\text { between } \\
\text { exceedances }\end{array}$ & $\begin{array}{l}\text { Max. } \\
\text { number of } \\
\text { days } \\
\text { between } \\
\text { exceedances }\end{array}$ & $\begin{array}{l}\text { Avg } \\
\text { of d } \\
\text { betv } \\
\text { excl }\end{array}$ \\
\hline $\begin{array}{l}\text { All Sites } \\
\text { (average) }\end{array}$ & & & & & $\begin{array}{l}45 \mathrm{y} \\
7 \mathrm{mo}\end{array}$ & 81.3 & 9.8 & 8.6 & 137.4 & 3995.8 & 128 \\
\hline Lerwick & -1.14 & 60.15 & -1.12 & 60.10 & $\begin{array}{l}62 \mathrm{y} \\
6 \mathrm{mo}\end{array}$ & 78.5 & 14 & 12 & 5.1 & 4622 & 114 \\
\hline Wick & -3.09 & 58.44 & -3.05 & 58.47 & $\begin{array}{l}56 y \\
6 \mathrm{mo}\end{array}$ & 91.8 & 4 & 4 & 772.3 & 2649.2 & 186 \\
\hline Moray Firth & -4.00 & 57.60 & -4.02 & 57.63 & $\begin{array}{l}10 \mathrm{y} \\
11 \mathrm{mo}\end{array}$ & 74.6 & 4 & 4 & 828.6 & 1820.6 & 124 \\
\hline Aberdeen & -2.08 & 57.14 & -2.06 & 57.17 & $\begin{array}{l}91 y \\
6 \mathrm{mo}\end{array}$ & 74.6 & 8 & 7 & 9.4 & 2577.7 & 137 \\
\hline Leith & -3.18 & 55.99 & -3.20 & 55.99 & $\begin{array}{l}40 y \\
6 \mathrm{mo}\end{array}$ & 85.7 & 20 & 18 & 2.1 & 9574.2 & 178 \\
\hline North Shields & -1.44 & 55.01 & -1.43 & 55.04 & $\begin{array}{l}75 y \\
6 \mathrm{mo}\end{array}$ & 82.7 & 5 & 5 & 318.8 & 6576.7 & 218 \\
\hline Whitby & -0.61 & 54.49 & -0.59 & 54.49 & $\begin{array}{l}41 y \\
6 \mathrm{mo}\end{array}$ & 81.5 & 11 & 9 & 4.3 & 6962.1 & 182 \\
\hline Immingham & -0.19 & 53.63 & -0.07 & 53.81 & $\begin{array}{l}68 \mathrm{y} \\
6 \mathrm{mo}\end{array}$ & 81.8 & 9 & 8 & 42 & 5814.5 & 154 \\
\hline Cromer & 1.30 & 52.93 & 1.33 & 52.92 & $\begin{array}{l}48 y \\
6 \mathrm{mo}\end{array}$ & 79.0 & 22 & 17 & 2 & 8042.4 & 178 \\
\hline Lowestoft & 1.75 & 52.47 & 1.75 & 52.45 & $\begin{array}{l}57 y \\
6 \mathrm{mo}\end{array}$ & 95.8 & 12 & 8 & 2.1 & 3344.5 & 800 \\
\hline Felixstowe & 1.35 & 51.96 & 1.38 & 51.98 & $\begin{array}{l}29 \mathrm{y} \\
11 \mathrm{mo}\end{array}$ & 85.6 & 6 & 6 & 463 & 2167.6 & 117 \\
\hline Harwich & 1.29 & 51.95 & 1.31 & 51.92 & $\begin{array}{l}67 y \\
6 \mathrm{mo}\end{array}$ & 78.9 & 8 & 7 & 4.1 & 4755.4 & 129 \\
\hline Sheerness & 0.74 & 51.45 & 0.74 & 51.50 & $\begin{array}{l}69 y \\
6 \mathrm{mo}\end{array}$ & 62.4 & 14 & 12 & 3.4 & 4762.2 & 126 \\
\hline Dover & 1.32 & 51.11 & 1.31 & 51.12 & $\begin{array}{l}97 y \\
6 \mathrm{mo}\end{array}$ & 76.3 & 11 & 10 & 49.2 & 2862.4 & 839 \\
\hline Newhaven & 0.06 & 50.78 & 0.02 & 50.78 & $\begin{array}{l}39 y \\
6 \mathrm{mo}\end{array}$ & 95.0 & 6 & 6 & 113.3 & 5000.6 & 139 \\
\hline Portsmouth & -1.11 & 50.80 & -1.09 & 50.74 & $\begin{array}{l}30 y \\
6 \mathrm{mo}\end{array}$ & 92.6 & 14 & 14 & 373.3 & 2575.8 & 128 \\
\hline Bournemouth & -1.87 & 50.71 & -1.90 & 50.71 & $\begin{array}{l}25 y \\
6 \mathrm{mo}\end{array}$ & 67.2 & 12 & 12 & 113.4 & 4790.6 & 151 \\
\hline St. Helier & -2.12 & 49.18 & -2.09 & 49.17 & $\begin{array}{l}29 y \\
6 \mathrm{mo}\end{array}$ & 85.1 & 15 & 14 & 307.8 & 6084.3 & 173 \\
\hline Weymouth & -2.45 & 50.61 & -2.47 & 50.57 & $\begin{array}{l}30 y \\
6 \mathrm{mo}\end{array}$ & 82.1 & 13 & 12 & 55.3 & 3967.2 & 154 \\
\hline Devonport & -4.19 & 50.37 & -4.18 & 50.33 & $\begin{array}{l}34 y \\
6 \mathrm{mo}\end{array}$ & 89.8 & 9 & 9 & 351.3 & 2218.7 & 117 \\
\hline Newlyn & -5.54 & 50.10 & -5.50 & 50.11 & $\begin{array}{l}106 y \\
6 \mathrm{mo}\end{array}$ & 88.2 & 8 & 7 & 243.2 & 2582.2 & 105 \\
\hline St. Marys & -6.32 & 49.92 & -5.71 & 50.11 & $\begin{array}{l}45 y \\
6 \mathrm{mo}\end{array}$ & 67.5 & 7 & 7 & 47.3 & 3275.2 & 138 \\
\hline Ilfracombe & -4.11 & 51.21 & -4.08 & 51.22 & $\begin{array}{l}53 y \\
6 \mathrm{mo}\end{array}$ & 79.1 & 6 & 6 & 392.3 & 2167.3 & 117 \\
\hline Hinkley Point & -3.13 & 51.22 & -3.10 & 51.20 & $\begin{array}{l}31 \mathrm{y} \\
6 \mathrm{mo}\end{array}$ & 86.3 & 8 & 7 & 44.3 & 4079 & 100 \\
\hline Portbury & -2.73 & 51.50 & -2.81 & 51.51 & $\begin{array}{l}13 y \\
6 \mathrm{mo}\end{array}$ & 48.4 & 11 & 10 & 7.5 & 5885.9 & 183 \\
\hline Avonmouth & -2.71 & 51.51 & -2.81 & 51.51 & $\begin{array}{l}51 y \\
3 \mathrm{mo}\end{array}$ & 79.1 & 16 & 13 & 4.1 & 2898.1 & 899 \\
\hline
\end{tabular}




\begin{tabular}{|c|c|c|c|c|c|c|c|c|c|c|c|}
\hline Newport & -2.99 & 51.55 & -2.97 & 51.54 & $\begin{array}{l}28 \mathrm{y} \\
6 \mathrm{mo}\end{array}$ & 73.1 & 15 & 13 & 4.2 & 3254.6 & 135 \\
\hline Mumbles & -3.98 & 51.57 & -3.99 & 51.57 & $\begin{array}{l}32 \mathrm{y} \\
11 \mathrm{mo}\end{array}$ & 61.2 & 5 & 5 & 10.8 & 2929.7 & 111 \\
\hline $\begin{array}{l}\text { Milford } \\
\text { Haven }\end{array}$ & -5.05 & 51.71 & -5.08 & 51.66 & $\begin{array}{l}68 \mathrm{y} \\
6 \mathrm{mo}\end{array}$ & 79.8 & 8 & 6 & 2 & 4126.4 & 124 \\
\hline Fishguard & -4.98 & 52.01 & -4.97 & 52.02 & $\begin{array}{l}58 \mathrm{y} \\
6 \mathrm{mo}\end{array}$ & 84.9 & 18 & 15 & 5.3 & 7349.9 & 172 \\
\hline Barmouth & -4.05 & 52.72 & -4.07 & 52.71 & $\begin{array}{l}30 y \\
6 \mathrm{mo}\end{array}$ & 65.5 & 5 & 3 & 4.6 & 2255.5 & 109 \\
\hline Holyhead & -4.62 & 53.31 & -4.62 & 53.27 & $\begin{array}{l}57 \mathrm{y} \\
6 \mathrm{mo}\end{array}$ & 86.2 & 10 & 8 & 34.2 & 4469.4 & 108 \\
\hline Llandudno & -3.83 & 53.33 & -3.79 & 53.31 & $\begin{array}{l}50 \mathrm{y} \\
6 \mathrm{mo}\end{array}$ & 87.4 & 10 & 8 & 0.9 & 3298.3 & 117 \\
\hline Liverpool & -3.02 & 53.45 & -3.07 & 53.49 & $\begin{array}{l}30 \mathrm{y} \\
6 \mathrm{mo}\end{array}$ & 80.4 & 9 & 9 & 383.7 & 2207.9 & 122 \\
\hline Heysham & -2.92 & 54.03 & -2.91 & 54.05 & $\begin{array}{l}57 y \\
6 \mathrm{mo}\end{array}$ & 80.2 & 2 & 1 & 125.8 & 125.8 & 125 \\
\hline Port Erin & -4.77 & 54.09 & -4.75 & 54.06 & $\begin{array}{l}29 y \\
6 \mathrm{mo}\end{array}$ & 93.9 & 6 & 6 & 658.2 & 2207.9 & 130 \\
\hline Workington & -3.57 & 54.65 & -3.57 & 54.66 & $\begin{array}{l}29 y \\
6 \mathrm{mo}\end{array}$ & 95.3 & 8 & 8 & 43.1 & 5141 & 228 \\
\hline Bangor & -5.67 & 54.66 & -5.68 & 54.69 & $\begin{array}{l}26 y \\
8 \mathrm{mo}\end{array}$ & 68.1 & 9 & 7 & 4.7 & 5940.1 & 169 \\
\hline Portpatrick & -5.12 & 54.84 & -5.12 & 54.84 & $\begin{array}{l}53 \mathrm{y} \\
6 \mathrm{mo}\end{array}$ & 85.7 & 7 & 7 & 392.2 & 2988.6 & 146 \\
\hline Portrush & -6.66 & 55.21 & -6.63 & 55.22 & $\begin{array}{l}26 y \\
6 \mathrm{mo}\end{array}$ & 86.6 & 11 & 7 & 1.4 & 2117.7 & 765 \\
\hline Port Ellen & -6.19 & 55.63 & -6.20 & 55.61 & $\begin{array}{l}32 \mathrm{y} \\
11 \mathrm{mo}\end{array}$ & 93.1 & 14 & 13 & 6.7 & 4037.4 & 135 \\
\hline Millport & -4.91 & 55.75 & -4.93 & 55.70 & $\begin{array}{l}43 y \\
6 \mathrm{mo}\end{array}$ & 83.9 & 6 & 5 & 25.8 & 2521.7 & 110 \\
\hline Tobermory & -6.06 & 56.62 & -6.10 & 56.76 & $\begin{array}{l}31 \mathrm{y} \\
6 \mathrm{mo}\end{array}$ & 87.7 & 7 & 6 & 8.4 & 1467.1 & 609 \\
\hline Ullapool & -5.16 & 57.90 & -5.37 & 57.96 & $\begin{array}{l}55 \mathrm{y} \\
6 \mathrm{mo}\end{array}$ & 84.4 & 17 & 16 & 22.3 & 10918.2 & 151 \\
\hline Stornoway & -6.39 & 58.21 & -6.32 & 58.17 & $\begin{array}{l}45 \mathrm{y} \\
6 \mathrm{mo}\end{array}$ & 84.5 & 10 & 9 & 25.9 & 4388.2 & 883 \\
\hline Kinlochbervie & -5.05 & 58.46 & -5.12 & 58.48 & $\begin{array}{l}30 \mathrm{y} \\
6 \mathrm{mo}\end{array}$ & 86.4 & 3 & 1 & 2.5 & 4.3 & 3.4 \\
\hline
\end{tabular}

Table 3: Information on the CCO study sites and the statistics of significant wave height exceedances at each site. 
1 in 1-year retum level

\begin{tabular}{|c|c|c|c|c|c|c|c|c|c|c|c|}
\hline Study site & Longitude & Latitude & $\begin{array}{l}\text { Nearest } \\
\text { CODEC } \\
\text { grid node } \\
\text { longitude }\end{array}$ & $\begin{array}{l}\text { Nearest } \\
\text { CODEC } \\
\text { grid } \\
\text { node } \\
\text { latitude }\end{array}$ & $\begin{array}{l}\text { Data } \\
\text { length }\end{array}$ & $\begin{array}{l}\text { Data } \\
\text { coverage } \\
(\%)\end{array}$ & $\begin{array}{l}\text { Exceedance } \\
\text { count }\end{array}$ & $\begin{array}{l}\text { Number of } \\
\text { seasons } \\
\text { with } \\
\text { exceedances }\end{array}$ & $\begin{array}{l}\text { Min. number } \\
\text { of days } \\
\text { between } \\
\text { exceedances }\end{array}$ & $\begin{array}{l}\text { Max. } \\
\text { number of } \\
\text { days } \\
\text { between } \\
\text { exceedances }\end{array}$ & $\begin{array}{l}\text { Avg. } \\
\text { of di } \\
\text { betu } \\
\text { exce }\end{array}$ \\
\hline $\begin{array}{l}\text { All Sites } \\
\text { (average) }\end{array}$ & & & & & $\begin{array}{l}11 \mathrm{y} \\
5 \mathrm{mo}\end{array}$ & 93.9 & 13.1 & 7.7 & 16.9 & 965.9 & 325. \\
\hline Newbiggin & -1.48 & 55.19 & -1.5 & 55 & $\begin{array}{l}7 y \\
9 \mathrm{mo}\end{array}$ & 96.8 & 23 & 6 & 0.7 & 456.5 & 86.6 \\
\hline Whitby & -0.61 & 54.50 & -0.5 & 55 & $\begin{array}{l}8 \mathrm{y} \\
2 \mathrm{mo}\end{array}$ & 87.2 & 8 & 5 & 16.1 & 478.4 & 296. \\
\hline Scarborough & -0.32 & 54.29 & 0 & 54.5 & $\begin{array}{l}8 \mathrm{y} \\
2 \mathrm{mo}\end{array}$ & 89.3 & 6 & 5 & 16.3 & 922.8 & 508. \\
\hline Hornsea & -0.06 & 53.92 & 0 & 54 & $\begin{array}{l}12 \mathrm{y} \\
9 \mathrm{mo}\end{array}$ & 97.9 & 5 & 4 & 0.7 & 2157.5 & 101; \\
\hline Chapel Point & 0.45 & 53.25 & 0.5 & 53 & $\begin{array}{l}8 \mathrm{y} \\
10 \mathrm{mo}\end{array}$ & 88.4 & 9 & 7 & 30 & 771.7 & 338. \\
\hline North Well & 0.48 & 53.06 & 0.5 & 53 & $\begin{array}{l}14 y \\
6 \mathrm{mo}\end{array}$ & 86.6 & 16 & 9 & 1.2 & 1393 & 333. \\
\hline $\begin{array}{l}\text { Blakeney } \\
\text { Overfalls }\end{array}$ & 1.11 & 53.06 & 1 & 53 & $\begin{array}{l}14 y \\
6 \mathrm{mo}\end{array}$ & 90.9 & 11 & 10 & 54.4 & 1044.2 & 483. \\
\hline Happisburgh & 1.55 & 52.83 & 1.5 & 53 & $\begin{array}{l}8 \mathrm{y} \\
10 \mathrm{mo}\end{array}$ & 83.8 & 6 & 5 & 30 & 1109.1 & 514. \\
\hline Lowestoft & 1.82 & 52.48 & 2 & 52.5 & $\begin{array}{l}4 \mathrm{y} \\
11 \mathrm{mo}\end{array}$ & 79.4 & 8 & 4 & 0.7 & 360 & 112. \\
\hline Felixstowe & 1.40 & 51.94 & 1.5 & 52 & $\begin{array}{l}8 \mathrm{y} \\
10 \mathrm{mo}\end{array}$ & 90.0 & 12 & 6 & 1 & 742.7 & 262. \\
\hline Herne Bay & 1.12 & 51.38 & 1 & 51.5 & $\begin{array}{l}9 \mathrm{y} \\
2 \mathrm{mo}\end{array}$ & 86.5 & 9 & 6 & 14.6 & 1176.3 & 378. \\
\hline $\begin{array}{l}\text { Goodwin } \\
\text { Sands }\end{array}$ & 1.49 & 51.25 & 1.5 & 51 & $\begin{array}{l}12 \mathrm{y} \\
9 \mathrm{mo}\end{array}$ & 97.9 & 18 & 8 & 3.1 & 1077.1 & 214 \\
\hline Deal Pier & 1.41 & 51.22 & 1.5 & 51 & $\begin{array}{l}9 \mathrm{y} \\
2 \mathrm{mo}\end{array}$ & 94.0 & 8 & 5 & 1 & 741.7 & 373. \\
\hline Folkestone & 1.13 & 51.06 & 1 & 51 & $\begin{array}{l}17 y \\
8 \mathrm{mo}\end{array}$ & 95.9 & 15 & 10 & 3.2 & 1372.6 & 392. \\
\hline Rye Bay & 0.79 & 50.85 & 1 & 51 & $\begin{array}{l}12 \mathrm{y} \\
6 \mathrm{mo}\end{array}$ & 94.9 & 7 & 3 & 1.7 & 417.5 & 184. \\
\hline $\begin{array}{l}\text { Pevensey } \\
\text { Bay }\end{array}$ & 0.42 & 50.78 & 0.5 & 50.5 & $\begin{array}{l}17 \mathrm{y} \\
8 \mathrm{mo}\end{array}$ & 96.3 & 20 & 12 & 1.8 & 1075.4 & 325 \\
\hline Seaford & 0.08 & 50.77 & 0 & 50.5 & $\begin{array}{l}13 y \\
2 \mathrm{mo}\end{array}$ & 96.2 & 17 & 11 & 2 & 692 & 294. \\
\hline Rustington & -0.49 & 50.73 & -0.5 & 50.5 & $\begin{array}{l}17 y \\
8 m o\end{array}$ & 96.8 & 18 & 10 & 1.9 & 1789.6 & 364. \\
\hline $\begin{array}{l}\text { Bracklesham } \\
\text { Bay }\end{array}$ & -0.84 & 50.72 & -1 & 50.5 & $\begin{array}{l}12 \mathrm{y} \\
7 \mathrm{mo}\end{array}$ & 97.5 & 11 & 5 & 3.7 & 1434.6 & 363. \\
\hline $\begin{array}{l}\text { Hayling } \\
\text { Island }\end{array}$ & -0.96 & 50.73 & -1 & 50.5 & $\begin{array}{l}17 y \\
8 \mathrm{mo}\end{array}$ & 96.9 & 28 & 16 & 1.9 & 758.5 & 217. \\
\hline $\begin{array}{l}\text { Sandown } \\
\text { Bay }\end{array}$ & -1.13 & 50.65 & -1 & 50.5 & $\begin{array}{l}17 \mathrm{y} \\
8 \mathrm{mo}\end{array}$ & 98.8 & 20 & 10 & 0.7 & 1836.9 & 321. \\
\hline Milford & -1.61 & 50.71 & -1.5 & 50.5 & $\begin{array}{l}24 \mathrm{y} \\
10 \mathrm{mo}\end{array}$ & 92.7 & 25 & 15 & 3.1 & 1462.3 & 367. \\
\hline Boscombe & -1.84 & 50.71 & -2 & 50.5 & $\begin{array}{l}17 y \\
8 m o\end{array}$ & 97.9 & 12 & 6 & 2.4 & 1845.4 & 555. \\
\hline Weymouth & -2.41 & 50.62 & -2.5 & 50.5 & $\begin{array}{l}14 y \\
3 m o\end{array}$ & 98.2 & 12 & 7 & 4.9 & 686 & 327. \\
\hline Chesil & -2.52 & 50.60 & -2.5 & 50.5 & $\begin{array}{l}15 \mathrm{y} \\
2 \mathrm{mo}\end{array}$ & 90.5 & 15 & 10 & 3.1 & 1002.5 & 311. \\
\hline West Bay & -2.75 & 50.69 & -2.5 & 50.5 & $\begin{array}{l}14 \mathrm{y} \\
4 \mathrm{mo}\end{array}$ & 96.5 & 15 & 12 & 3.1 & 984.5 & 344. \\
\hline
\end{tabular}




\begin{tabular}{|c|c|c|c|c|c|c|c|c|c|c|c|}
\hline Dawlish & -3.42 & 50.58 & -3.5 & 50.5 & $\begin{array}{l}10 y \\
3 \mathrm{mo}\end{array}$ & 98.3 & 10 & 5 & 9.9 & 645.8 & 309. \\
\hline Tor Bay & -3.52 & 50.43 & -3.5 & 50.5 & $\begin{array}{l}12 y \\
8 m o\end{array}$ & 90.1 & 20 & 8 & 0.7 & 982.8 & 169 \\
\hline Start Bay & -3.62 & 50.29 & -3.5 & 50.5 & $\begin{array}{l}13 \mathrm{y} \\
11 \mathrm{mo}\end{array}$ & 97.7 & 12 & 9 & 1.2 & 834.9 & 425. \\
\hline Looe Bay & -4.41 & 50.34 & -4.5 & 50 & $\begin{array}{l}11 y \\
9 \mathrm{mo}\end{array}$ & 98.5 & 9 & 7 & 9.4 & 1089.5 & 329. \\
\hline Porthleven & -5.31 & 50.06 & -5.5 & 50 & $\begin{array}{l}9 \mathrm{y} \\
5 \mathrm{mo}\end{array}$ & 97.1 & 12 & 8 & 3.1 & 616.9 & 280. \\
\hline Penzance & -5.50 & 50.11 & -5.5 & 50 & $\begin{array}{l}13 \mathrm{y} \\
11 \mathrm{mo}\end{array}$ & 98.3 & 19 & 11 & 0.8 & 1041.5 & 242. \\
\hline $\begin{array}{l}\text { St. Mary's } \\
\text { Sound }\end{array}$ & -6.31 & 49.89 & -6.5 & 50 & $\begin{array}{l}6 y \\
10 \mathrm{mo}\end{array}$ & 96.2 & 7 & 4 & 66.7 & 400.4 & 241. \\
\hline Wave Hub & -5.61 & 50.35 & -5.5 & 50.5 & $\begin{array}{l}2 \mathrm{y} \\
11 \mathrm{mo}\end{array}$ & 95.8 & 4 & 3 & 5 & 616.2 & 231. \\
\hline Perranporth & -5.17 & 50.35 & -5 & 50.5 & $\begin{array}{l}14 y \\
4 \mathrm{mo}\end{array}$ & 96.6 & 20 & 12 & 1.7 & 1372.8 & 254. \\
\hline Bideford Bay & -4.28 & 51.06 & -4.5 & 51 & $\begin{array}{l}11 y \\
9 m o\end{array}$ & 96.0 & 9 & 6 & 1 & 778.4 & 279. \\
\hline Minehead & -3.47 & 51.23 & -3 & 51.5 & $\begin{array}{l}14 y \\
3 m o\end{array}$ & 93.5 & 15 & 10 & 1.5 & 749 & 325. \\
\hline Weston Bay & -3.02 & 51.35 & -3 & 51.5 & $\begin{array}{l}11 y \\
6 m o\end{array}$ & 96.1 & 18 & 9 & 2.5 & 766.3 & 231. \\
\hline Rhyl Flats & -3.60 & 53.38 & -3.5 & 53.5 & $\begin{array}{l}13 y \\
9 m o\end{array}$ & 94.6 & 14 & 7 & 14.5 & 1104.9 & 306. \\
\hline Gwynt y Môr & -3.50 & 53.48 & -3.5 & 53.5 & $\begin{array}{l}12 \mathrm{y} \\
1 \mathrm{mo}\end{array}$ & 88.5 & 14 & 7 & 32.5 & 1086.9 & 252. \\
\hline $\begin{array}{l}\text { New } \\
\text { Brighton }\end{array}$ & -3.03 & 53.44 & -3 & 53.5 & $\begin{array}{l}1 \mathrm{y} \\
8 \mathrm{mo}\end{array}$ & 89.2 & 2 & 2 & 340.1 & 340.1 & 340. \\
\hline Cleveleys & -3.20 & 53.89 & -3 & 54 & $\begin{array}{l}9 y \\
9 \mathrm{mo}\end{array}$ & 96.9 & 11 & 9 & 31.7 & 700.5 & 295. \\
\hline $\begin{array}{l}\text { Morecombe } \\
\text { Bay }\end{array}$ & -3.06 & 53.99 & -3 & 54 & $\begin{array}{l}9 \mathrm{y} \\
9 \mathrm{mo}\end{array}$ & 98.1 & 13 & 8 & 1 & 616 & 188. \\
\hline
\end{tabular}

\section{Figures}




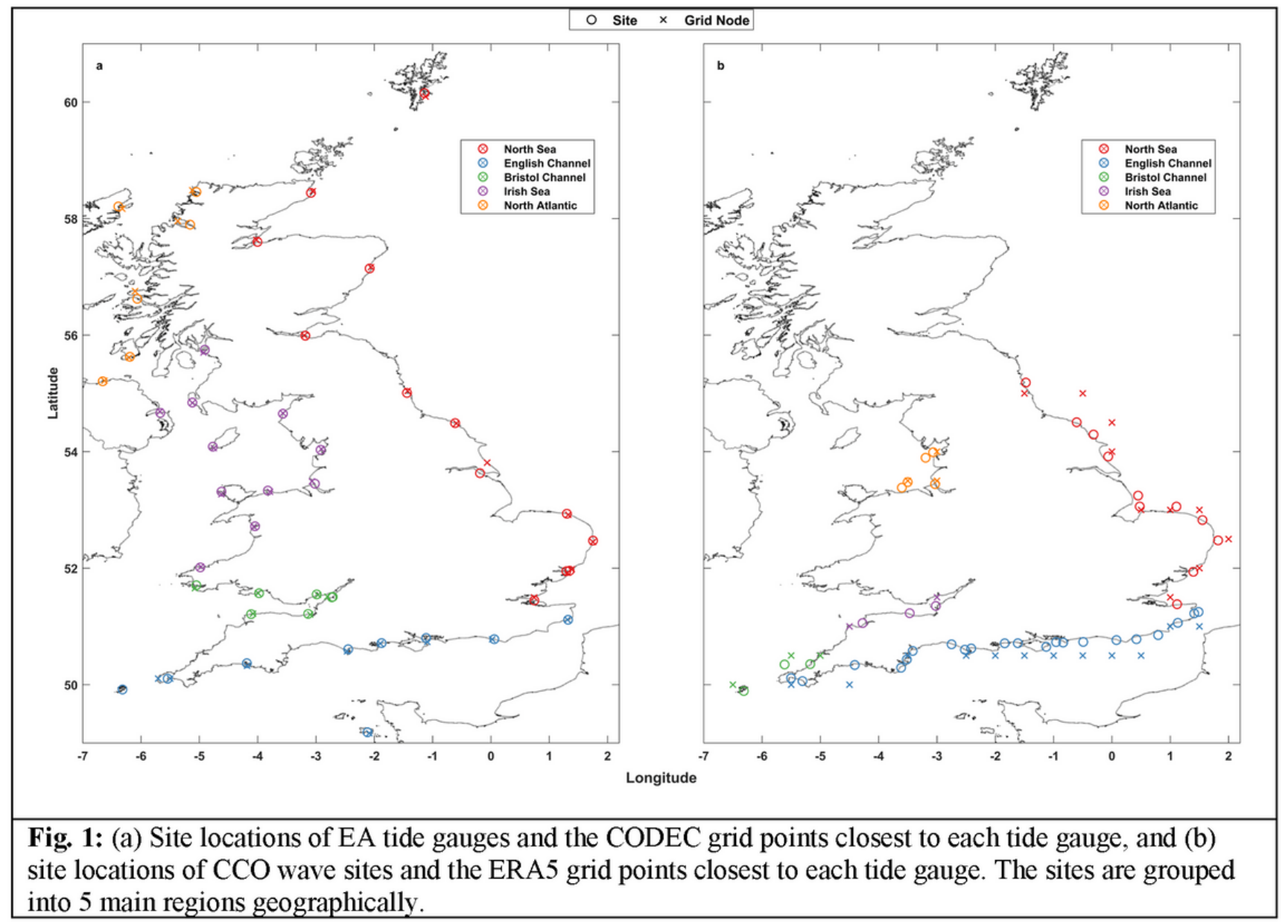

Figure 1

See image above for figure legend. 


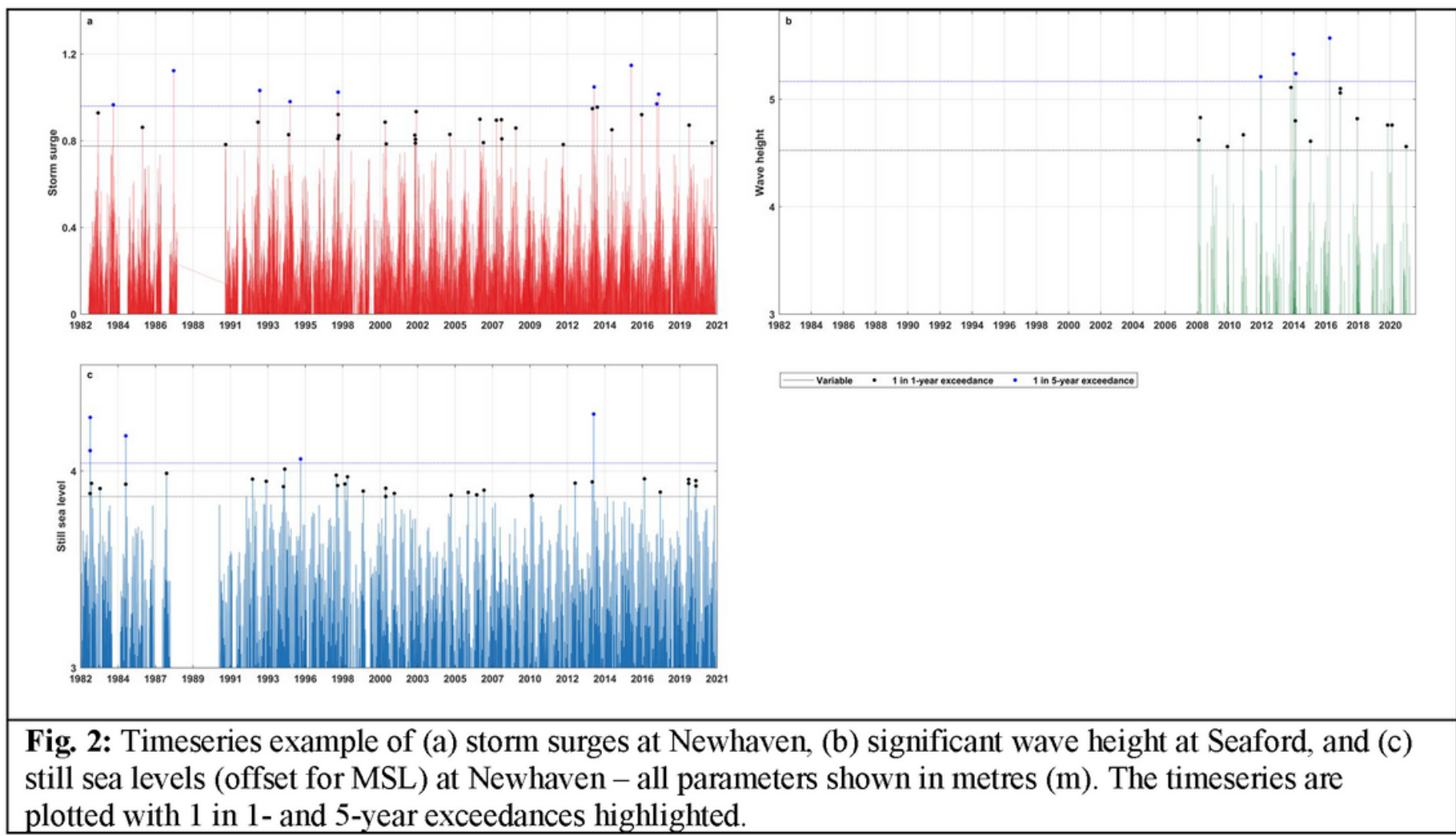

Figure 2

See image above for figure legend. 


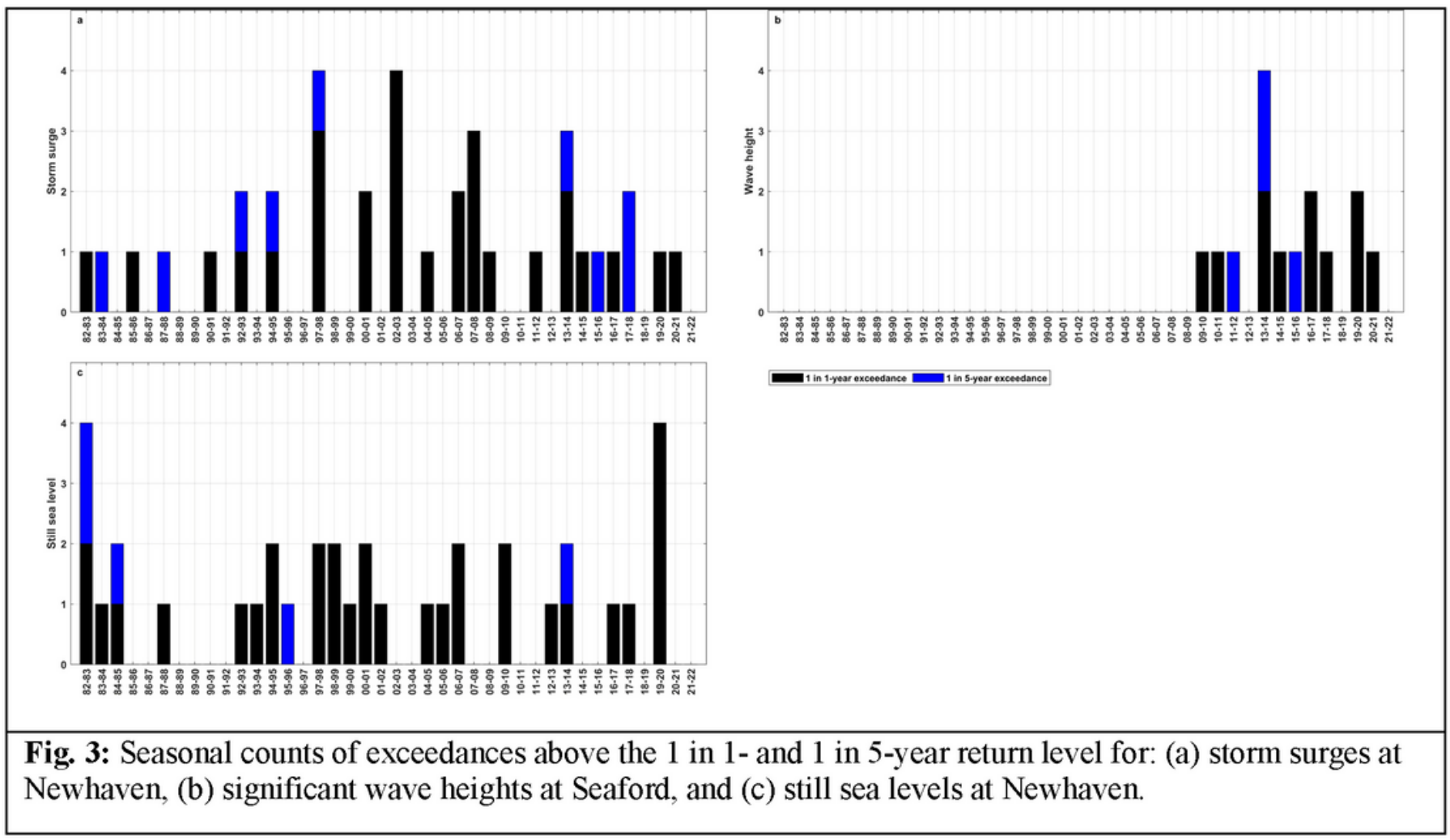

Figure 3

See image above for figure legend. 


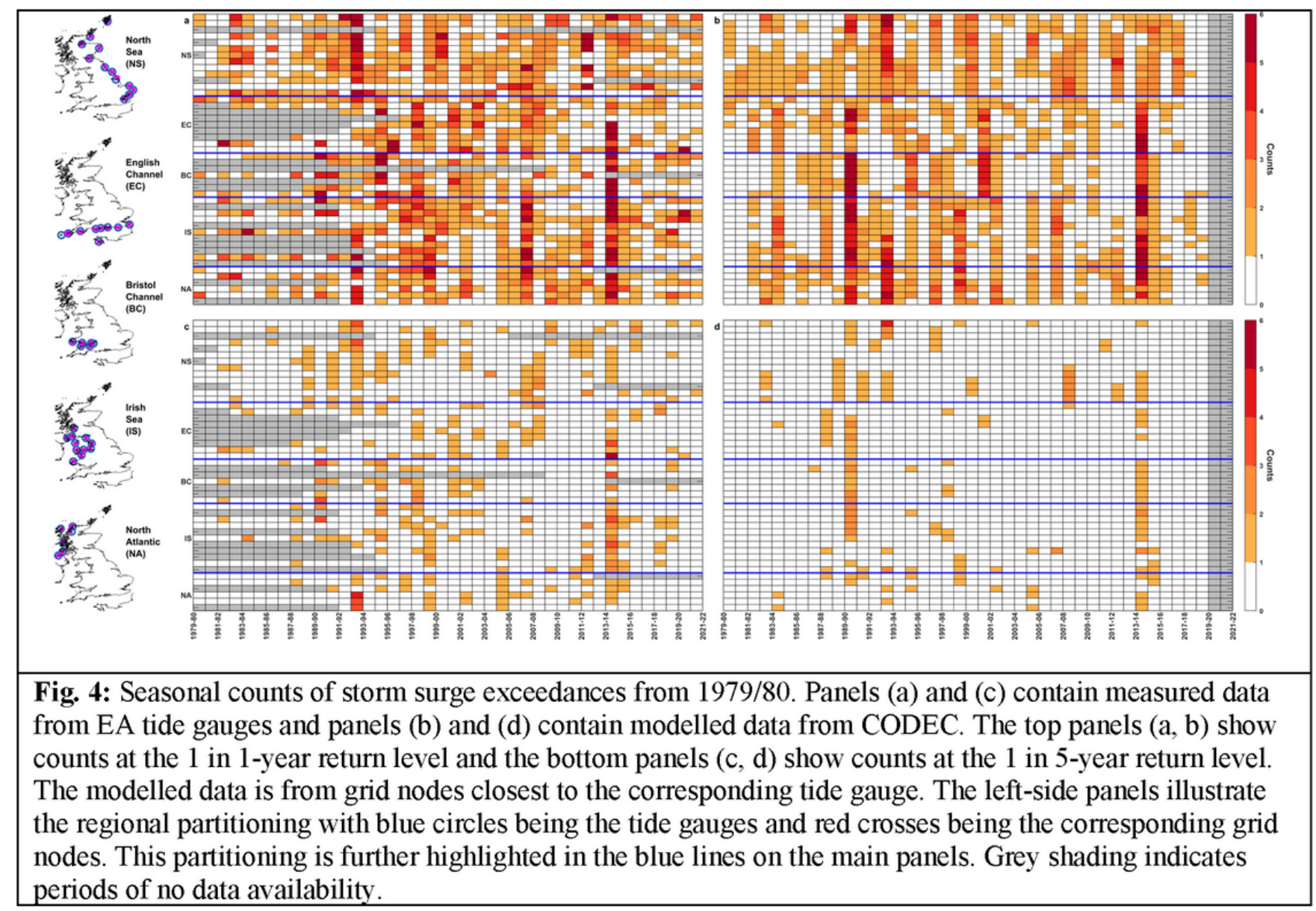

Figure 4

See image above for figure legend. 


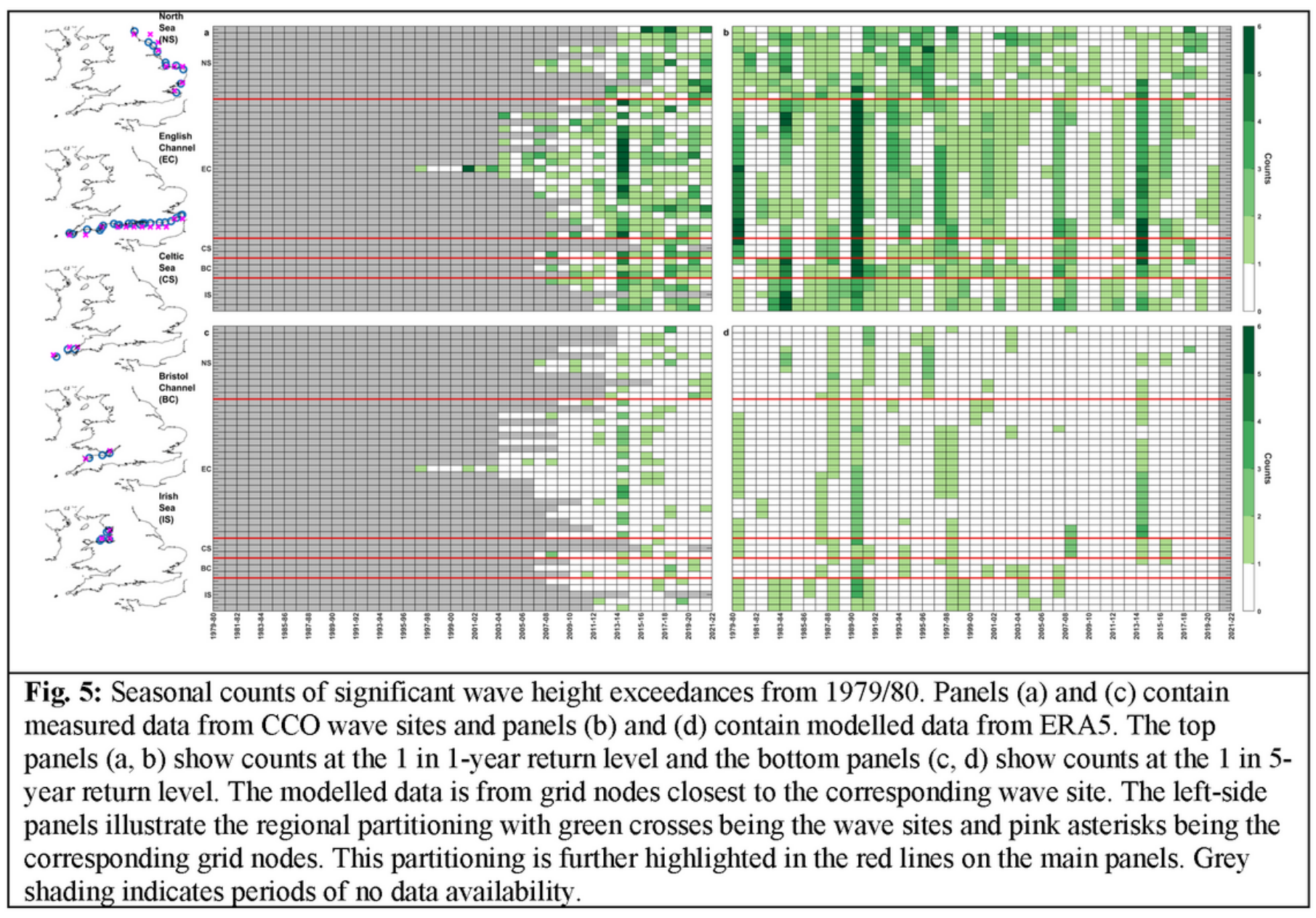

Figure 5

See image above for figure legend. 


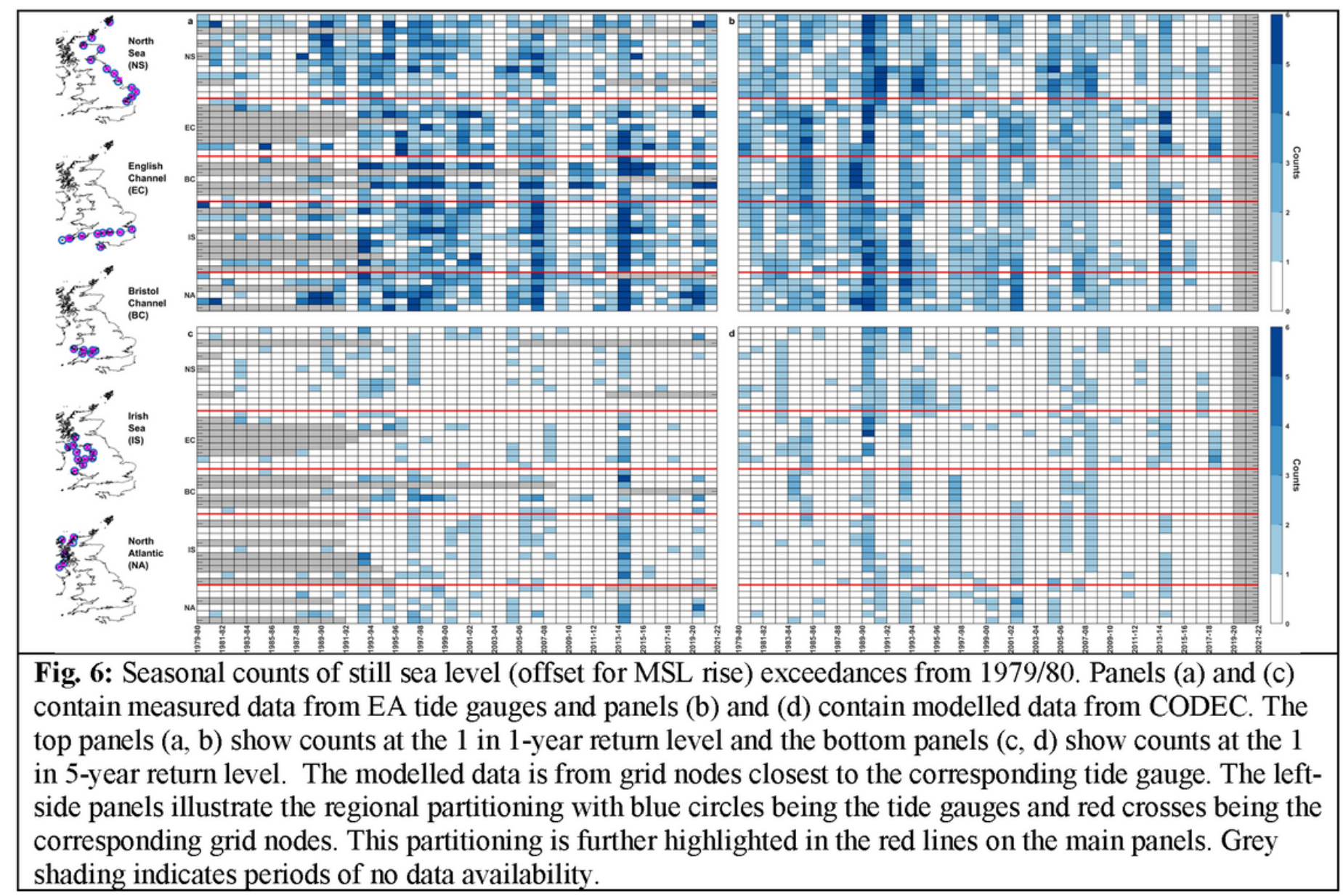

Figure 6

See image above for figure legend. 


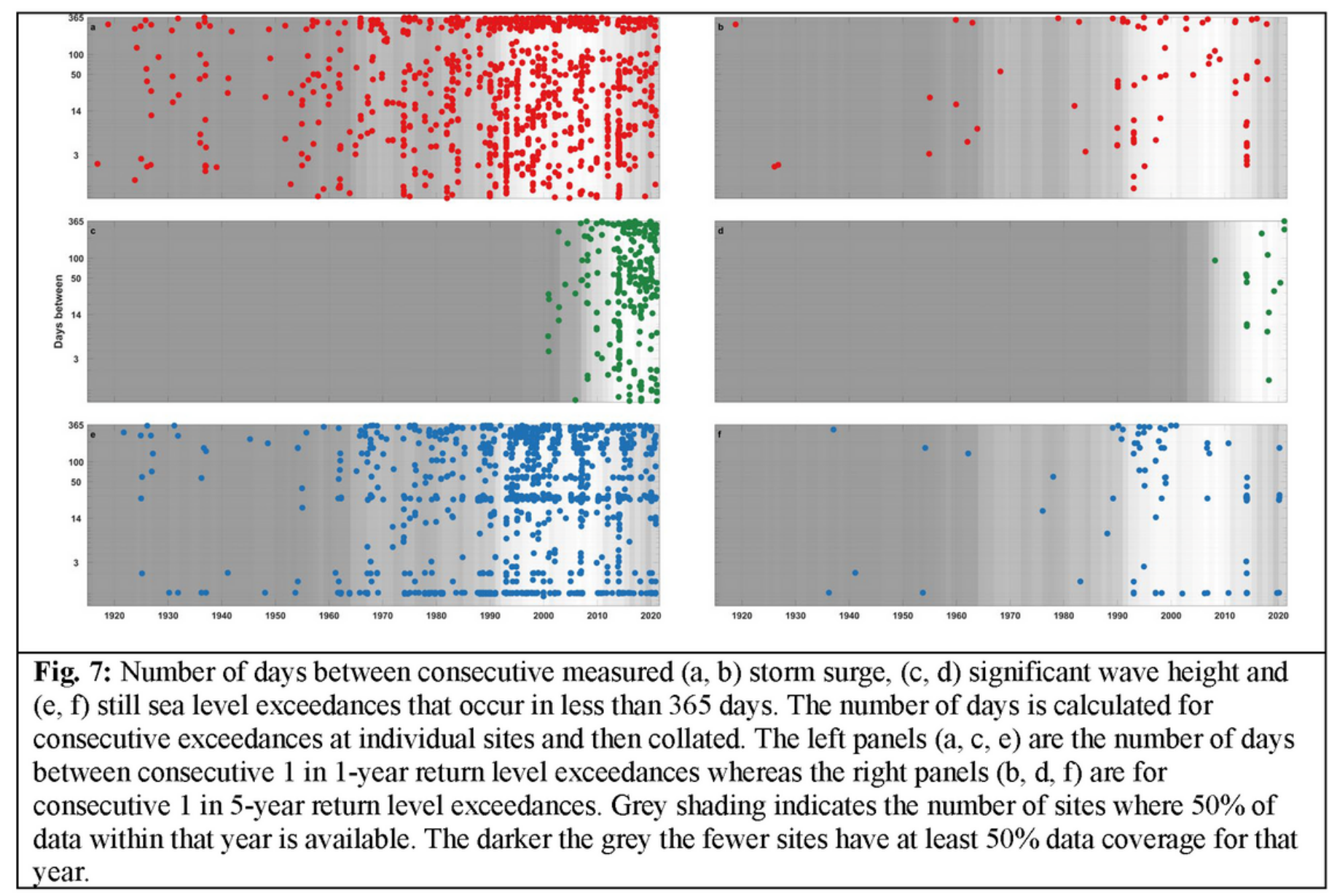

Figure 7

See image above for figure legend. 


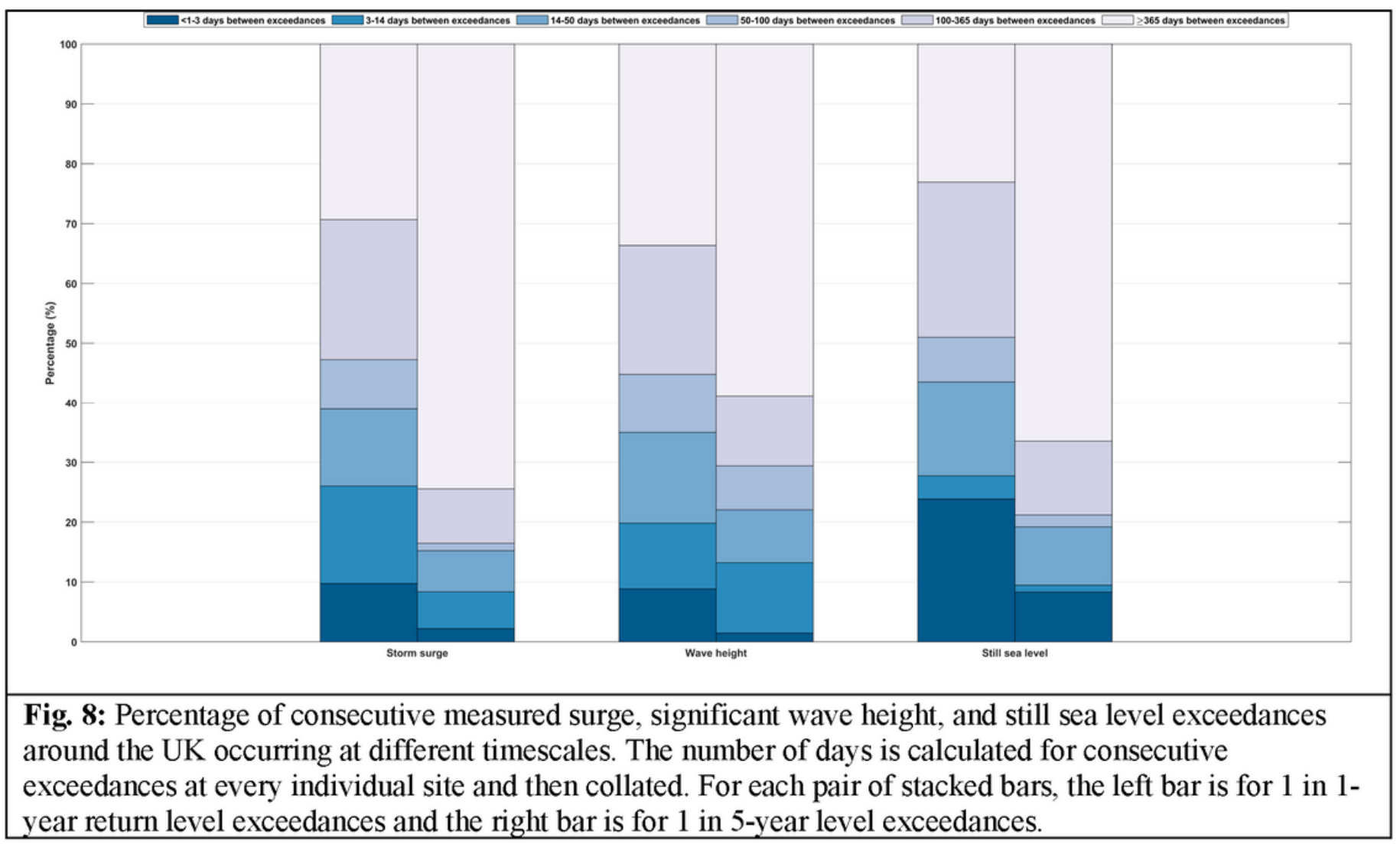

Figure 8

See image above for figure legend. 


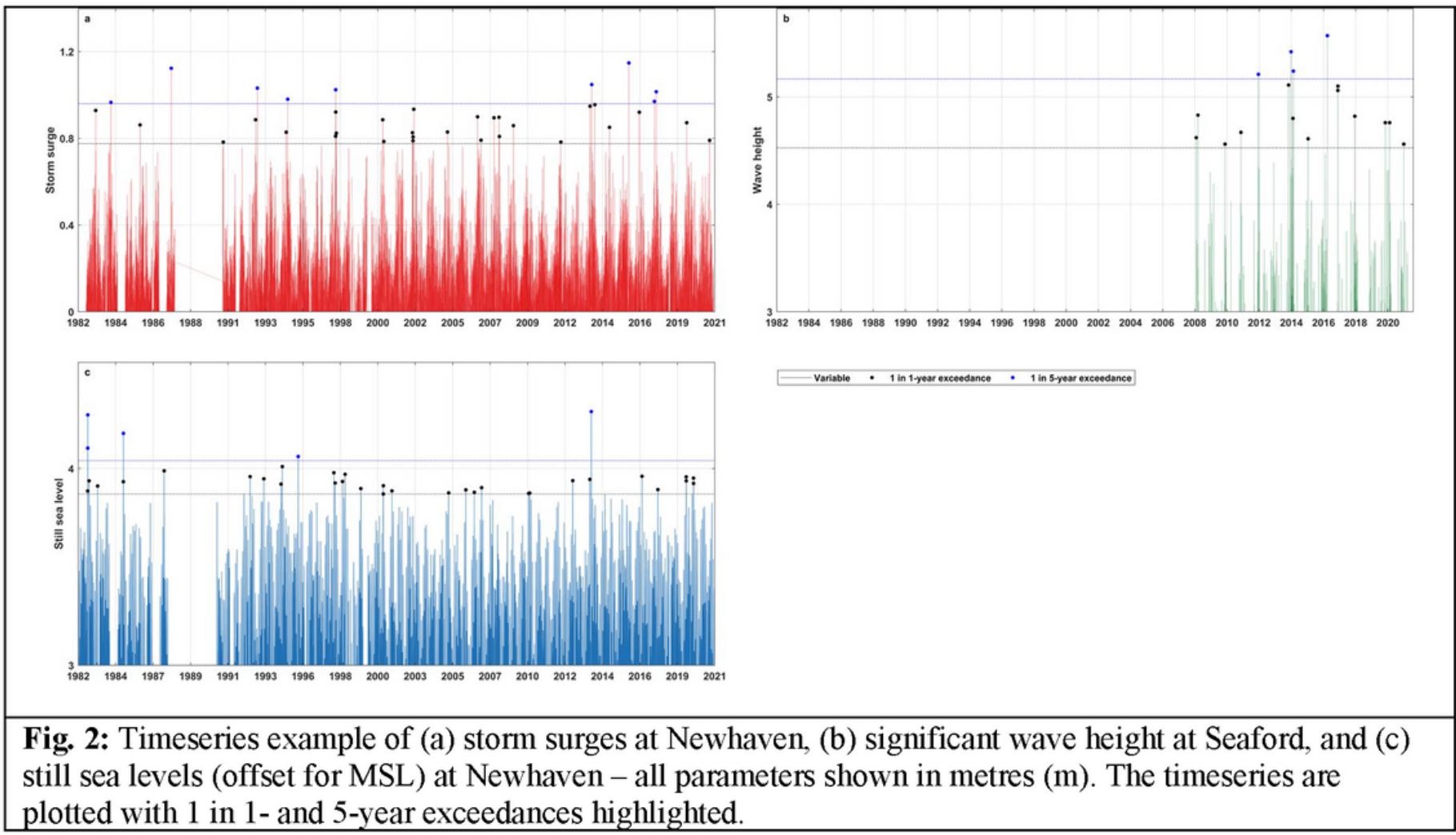

Figure 9 


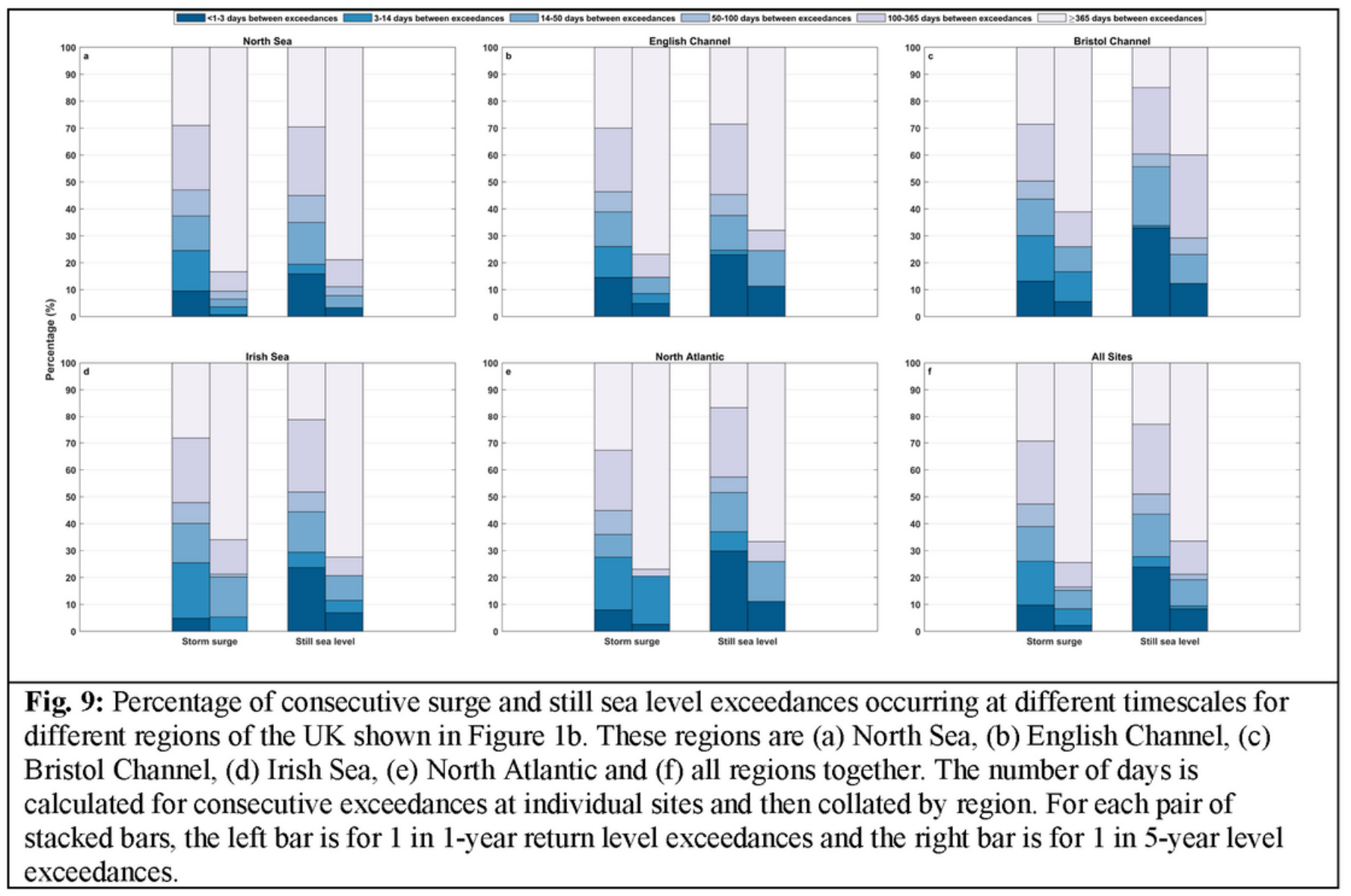

Figure 9

See image above for figure legend. 


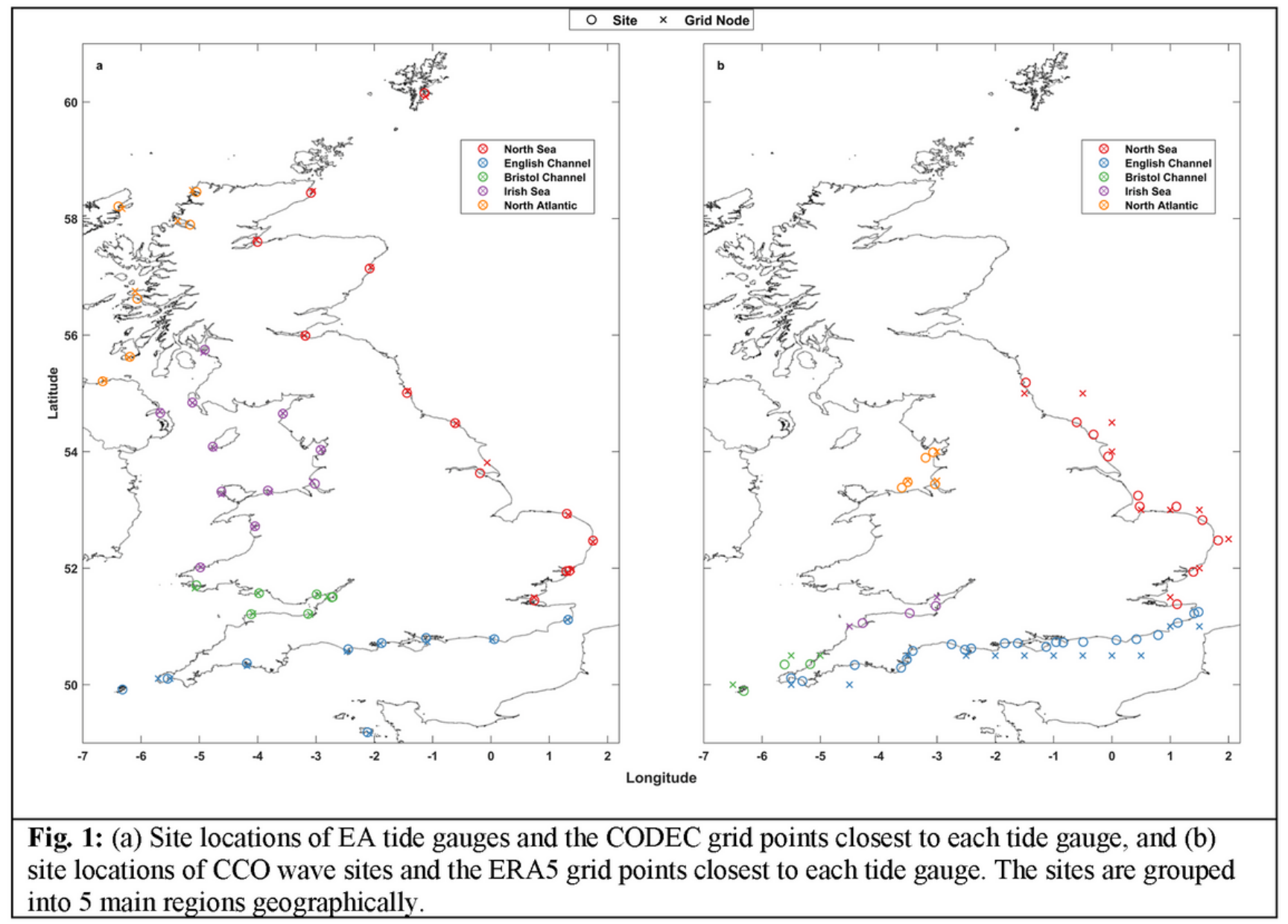

Figure 10 


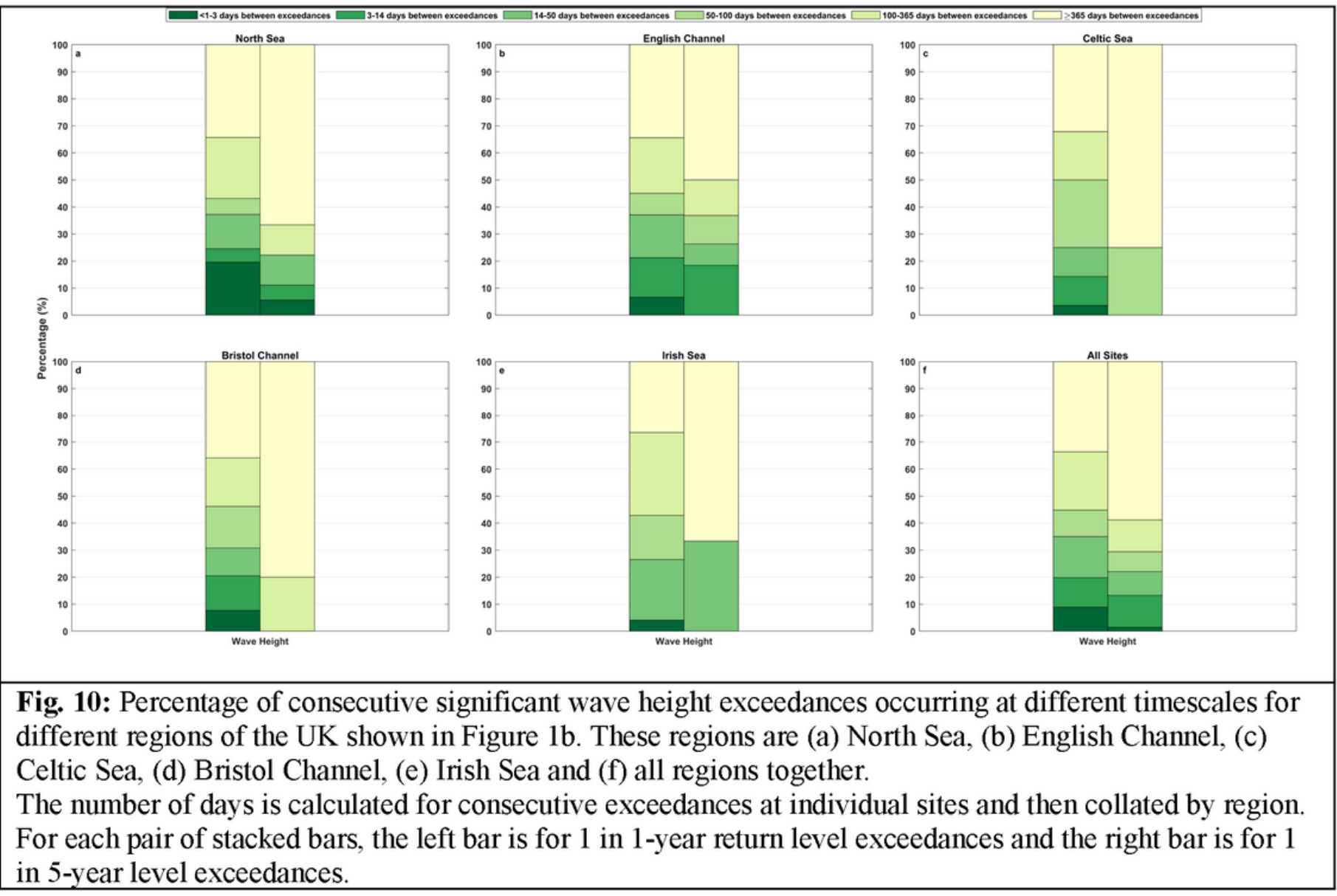

Figure 10

See image above for figure legend.

\section{Supplementary Files}

This is a list of supplementary files associated with this preprint. Click to download.

- SILJJ.docx 